\title{
5. FORAMINIFERAL BIOFACIES, PALEOENVIRONMENTS, AND BIOSTRATIGRAPHY OF NEOGENE-QUATERNARY SEDIMENTS, CASCADIA MARGIN ${ }^{1}$
}

\author{
Sarah D. Zellers ${ }^{2}$
}

\begin{abstract}
Five sites along the Cascadia accretionary wedge west of Vancouver Island and Oregon were investigated during Leg 146. Analyses of planktonic and benthic foraminifers provide information on the age, paleoceanography, and paleoenvironments of the sediments obtained along the margin. Upper Quaternary sediments, representing turbidites deposited in a lower bathyal environment under mainly cold surface waters, were recovered at Site 888. A discontinuous sequence of upper Pliocene through Quaternary abyssal plain and interslope basin sediments, deposited in lower bathyal through middle bathyal environments, was drilled at Sites $889 / 890$. Surface water temperatures ranged from cool temperate during the Pliocene to cold during the Pleistocene. Site 891 contains Quaternary turbidites deposited in a lower bathyal environment beneath dominantly cold surface waters. A structurally complex series of lower bathyal sediments, indicative of a variety of ages ranging from Pleistocene to Miocene, and possibly Eocene, was recovered at Site 892.
\end{abstract}

\section{INTRODUCTION}

Drilling on Ocean Drilling Program (ODP) Leg 146 was aimed at investigating fluid flow and sediment deformation within the Cascadia accretionary wedge. Two regions were drilled along the Cascadia margin: three sites off Vancouver Island and two sites off Oregon (Fig. 1). The overall objectives of this leg were to define the budget, sources, and pathways of sediment, water, and dissolved chemicals within the accretionary wedge.

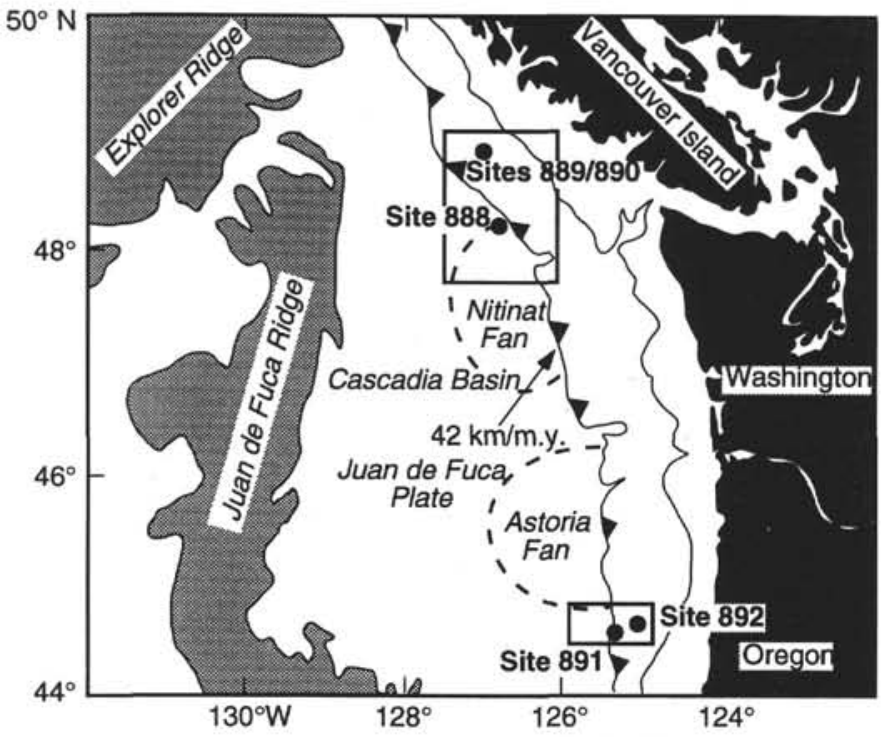

Figure 1. Map of the Cascadia Margin, showing the position of drilling sites off Vancouver Island and Oregon, convergence of the Juan de Fuca Plate, and major physiographic features in the Cascadia Basin.

'Carson, B., Westbrook, G.K., Musgrave, R.J., and Suess, E. (Eds.), 1995. Proc. ODP, Sci. Results, Vol. 146 (Pt. 1): College Station, TX (Ocean Drilling Program).

${ }^{2}$ Department of Geological Sciences, The University of Texas at Austin, Austin, TX U.S.A. (Present address: Central Exploration Department, Texaco, Inc., 4800 Fournace Place, Bellaire, TX 77401, U.S.A.
Detailed age control and paleoenvironmental determinations are fundamental for understanding the geologic history of the Cascadia margin. Age control is essential for documenting the timing of deformational events, and paleobathymetric data can constrain the amount of vertical movement along the margin. Age determinations for Cascadia margin sites are based on the integration of magnetostratigraphy and foraminifer, radiolarian, and diatom biostratigraphy. Paleobathymetry is determined from paleoenvironmentally significant benthic foraminiferal biofacies. Planktonic foraminifers also provide insight into the paleoceanographic and paleoclimatic history of the margin.

This paper describes the distribution of foraminifers obtained on Leg 146. Specific objectives of the foraminiferal analyses are as follows: (1) characterize planktonic foraminiferal faunas in order to determine age relationships and provide insight into the paleoceanographic and paleoclimatic history of the Cascadia margin; and (2) document and analyze benthic foraminiferal assemblages in order to determine paleoenvironments and document changes in paleobathymetry along the margin.

\section{METHODS}

The following standard processing technique was used for extracting foraminifers. Approximately $10 \mathrm{~cm}^{3}$ of sediment was boiled for $30 \mathrm{~min}$ in a $4 \%$ Calgon and water solution and then wet-sieved over a $63-\mu \mathrm{m}$ screen. The solvent "Quaternary O" was used to wash indurated samples. The residue was dried in an oven, sieved at 149 $\mu \mathrm{m}$, and at least 300 foraminifers were picked, abundance permitting. Fossiliferous samples were split with a microsplitter until one tray contained approximately 300 specimens. The fraction that measured between 63 and $149 \mu \mathrm{m}$ was scanned.

Abundances of planktonic foraminifers are given in absolute counts of the faunas picked. Relative abundances of benthic foraminifers per sample are reported as follows: present $(X)=1$ specimen, rare $(R)=2-9$ specimens, few $(F)=10-24$ specimens, common $(C)$ $=25-74$ specimens, and abundant $(\mathrm{A})=75$ or more specimens.

Three classes of foraminifer preservation were used: $\mathrm{G}=$ good ( $>90 \%$ of the specimens were unbroken and well preserved); $M=$ moderate $(30-90 \%$ of the specimens were fragmented or showed evidence of dissolution and/or recrystallization); and $\mathrm{P}=$ poor (almost 
all of the specimens were fragmented and showed evidence of dissolution and/or recrystallization).

A comprehensive species list is provided in the Appendix. The faunas examined are well illustrated in several publications (Barker, 1960; Haller, 1980; Saito et al., 1981; Kennett and Srinivasan, 1983; Finger, 1990) and are therefore not further illustrated here. Taxonomy of planktonic species follows that of Saito et al. (1981), supplemented by Kennett and Srinivasan (1983).

\section{Chronological Framework}

Direct application of low-latitude zonations such as that of Blow (1969) is often difficult or inappropriate for the northeast Pacific Ocean because of the temperate nature of the faunas. Therefore, foraminifer age determinations on Leg 146 were constrained by the chronostratigraphic framework developed by Lagoe and Thompson (1988) for the temperate northeast Pacific (Fig. 2). This framework is based on planktonic foraminifer evolutionary datums (first and last occurrences) and paleoclimatically controlled shifts in Neogloboquadrina pachyderma. Lagoe and Thompson (1988) constructed a generalized coiling curve for the northeastern Pacific containing 16 correlative coiling intervals $(\mathrm{CD}=$ coiling dominance; Fig. 2). For the purposes of this study, the CDI to CD7 zones of Lagoe and Thompson were grouped to represent a zone of high-frequency coiling shifts with mixed coiling directions from $367 \mathrm{ka}$ to the present. Ages given by Lagoe and Thompson (1988) were converted to the time scale of Cande and Kent (1992) (see Shipboard Scientific Party, 1994a).

Age determinations based on coiling ratios of $N$. pachyderma are constrained by magnetostratigraphy and radiolarian biostratigraphy described in the Initial Reports for Leg 146 (Westbrook, Carson, Musgrave, et al., 1994) and additional microfossil studies (Caulet, this volume; Fourtanier, this volume).

\section{Paleoenvironmental Analyses}

Benthic foraminifers were examined to determine paleoenvironments and to infer paleobathymetry. Paleoenvironmental zonation was modified from Ingle (1980) as follows: inner neritic $(0-50 \mathrm{~m})$, outer neritic $(50-150 \mathrm{~m})$, upper bathyal $(150-500 \mathrm{~m})$, upper middle bathyal (500-1500 m), lower middle bathyal (1500-2000 m), lower bathyal $(2000-4000 \mathrm{~m})$, and abyssal $(4000+)$. Minimum paleobathymetric estimations are based on the deepest dwelling faunas present in a sample, or in an interval of similar strata (e.g. turbidites).

It is necessary to distinguish paleoenvironmental terminology from terms describing physiography. Paleoenvironments are defined on the basis of benthic foraminifers characteristic of depth-related water masses. Terms indicating depositional environments (shelf, slope, abyssal plain) refer to physiographic features. Many of the sediments recovered during Leg 146 were deposited in an abyssal plain depositional environment, in the lower bathyal paleoenvironmental zone.

\section{Lithostratigraphy and Structural Geology}

Paleoenvironmental interpretations are derived from benthic foraminiferal biofacies (see below), but are also constrained by lithostratigraphic and structural data and interpretations. For each site, this paper provides a summary of the lithostratigraphy, interpretation of depositional environments, and relevant structural information derived from the site chapters of the Initial Reports for Leg 146 (Westbrook, Carson, Musgrave, et al., 1994).

\section{VANCOUVER MARGIN: SITES 888, 889, AND 890}

\section{Site 888}

Site 888 is located on the outer part of the Nitinat submarine fan, $7 \mathrm{~km}$ seaward of the accretionary wedge off Vancouver Island

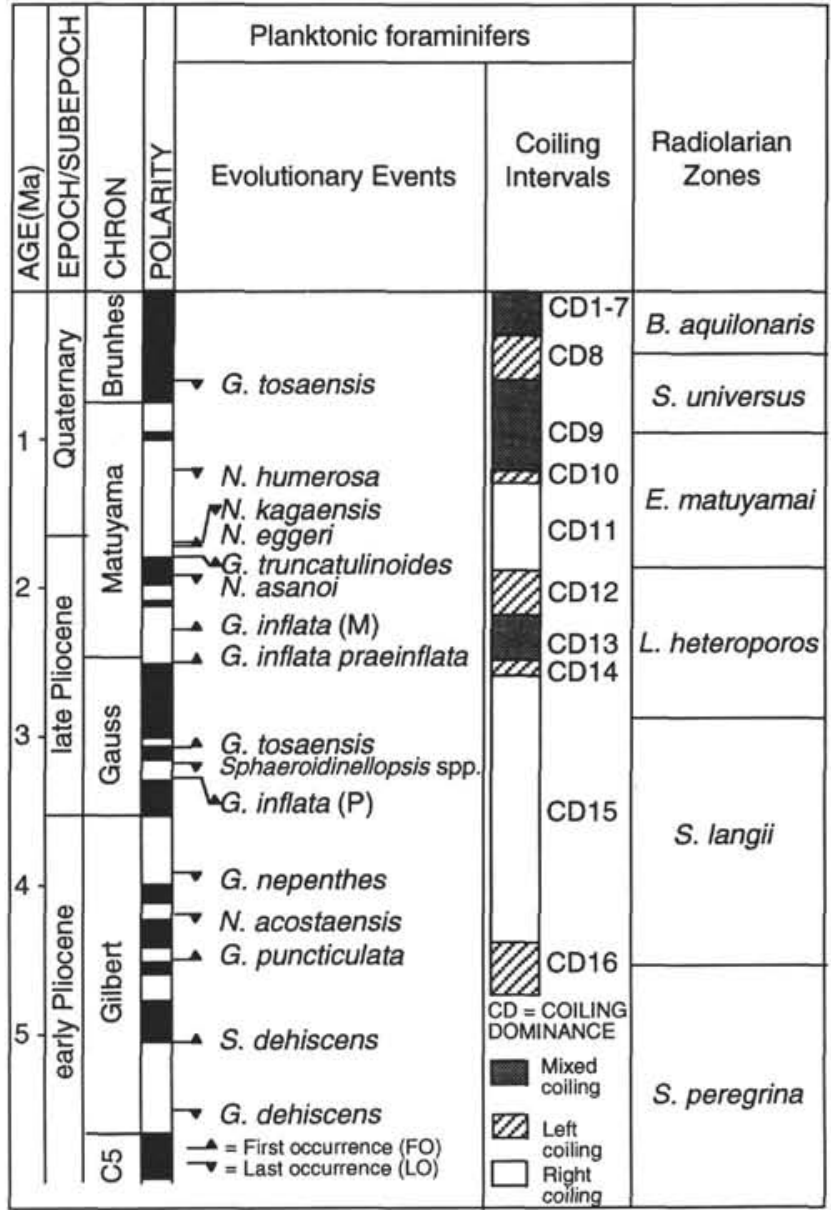

Figure 2. Correlation of radiolarian zones, planktonic foraminiferal evolutionary events, and coiling zones of Neogloboquadrina pachyderma as defined by Lagoe and Thompson (1988) to the magnetic polarity time scale of Cande and Kent (1992) (after Lagoe and Thompson, 1988, and Shipboard Scientific Party, 1994a).

$\left(48^{\circ} 10.009 \mathrm{~N}, 126^{\circ} 39.794 \mathrm{~W}\right)$ at $2516 \mathrm{~m}$ below sea level (mbsl) (Fig. 1). This site was selected as a reference site for type, age, and physical properties of sediments that occur within the accretionary wedge.

Three lithostratigraphic units were recognized (Fig. 3). Lithostratigraphic Unit I (0-175.1 meters below seafloor, or mbsf) consists of interbedded clayey silts, medium-grained sands, with some thin beds containing pebbles, volcaniclastic fragments, and plant material. Below Unit I is a transitional zone, marked by an increase with depth in the amount of massive sand. Unit II (193.0-457.0 mbsf) contains poorly sorted, massive, fine- to medium-grained sand with interbeds of clayey silt. The lowest unit, Unit III (457.0-566.9 mbsf), consists of firm clayey silt and sand, laminated with thin interbeds of coarse sand and gravels.

Sediments at Site 888 are interpreted to be turbidites deposited as part of the Nitinat submarine fan system. Unit I represents deposition by low-energy, low-density turbidity currents on the outer or distal portion of the submarine fan. Sediments in Unit II are characteristic of deposition on the middle portion of a submarine fan. Lithostratigraphic Unit III is similar to Unit I, but appears to be more distal than Unit I (based on the amount of sand) and represents an abyssal plain depositional environment.

\section{Planktonic Foraminifers}

Moderately to well-preserved Quaternary planktonic foraminifers are rare to abundant in samples from Holes 888A and 888B (Table 1). 


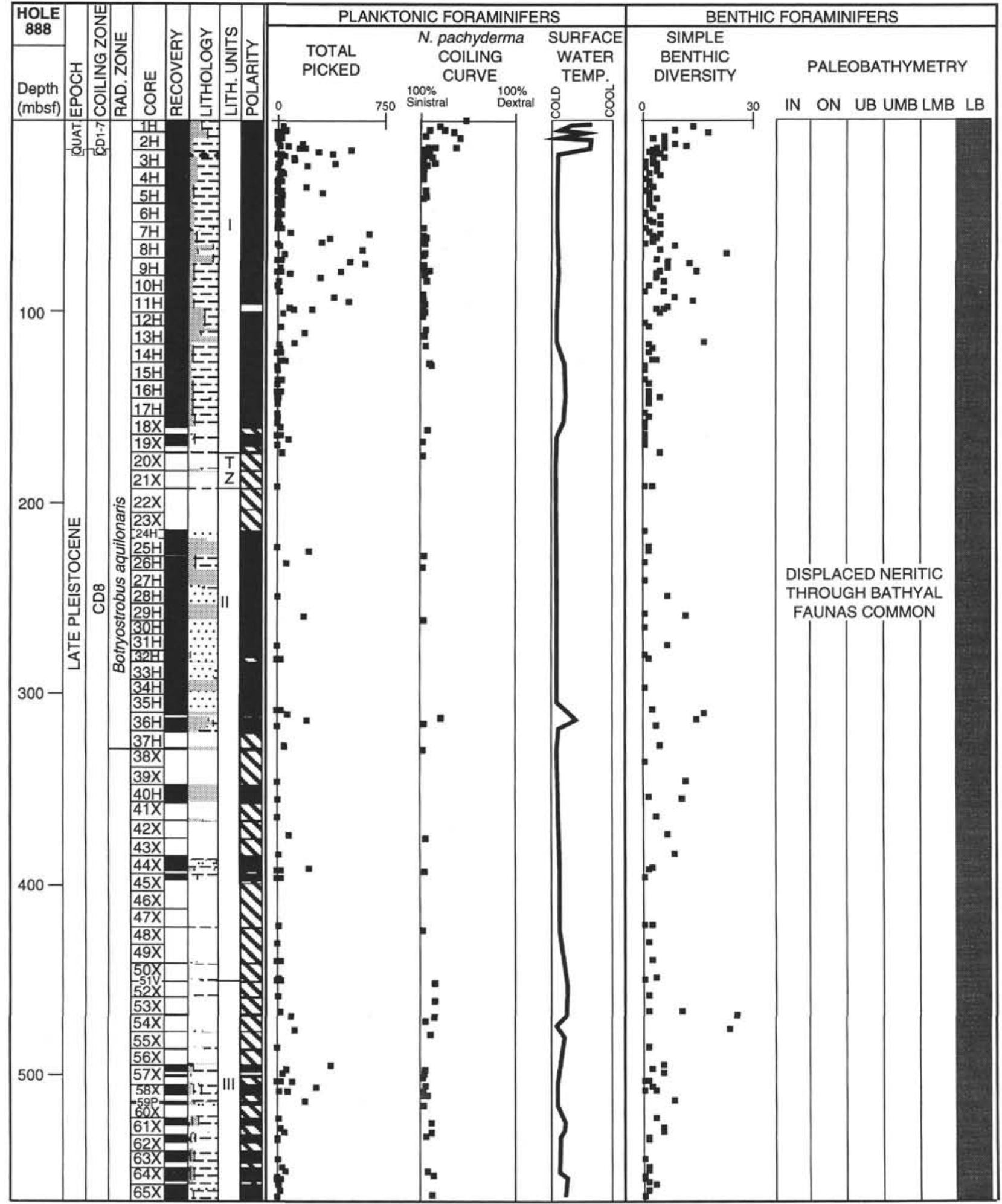

Figure 3. Summary of age zonation, core recovery, lithology, magnetic polarity, foraminiferal distributions, inferred sea-surface temperatures, and paleobathymetry at Site 888. Key to lithologic symbols: thin dashed pattern = silty clay and clayey silt; coarse stipple = silty sand and sandy silt; fine stipple = sand; thick dashed pattern = gravel. Key to polarity units: black = normal polarity; white = reversed polarity; diagonal = undetermined. TZ indicates a transition zone between lithologic Units I and II. See Shipboard Scientific Party (1994b) for radiolarian zonations and more detailed lithologic and paleomagnetic information. 
Table 1. Checklist of foraminifers found at Site $\mathbf{8 8 8 .}$

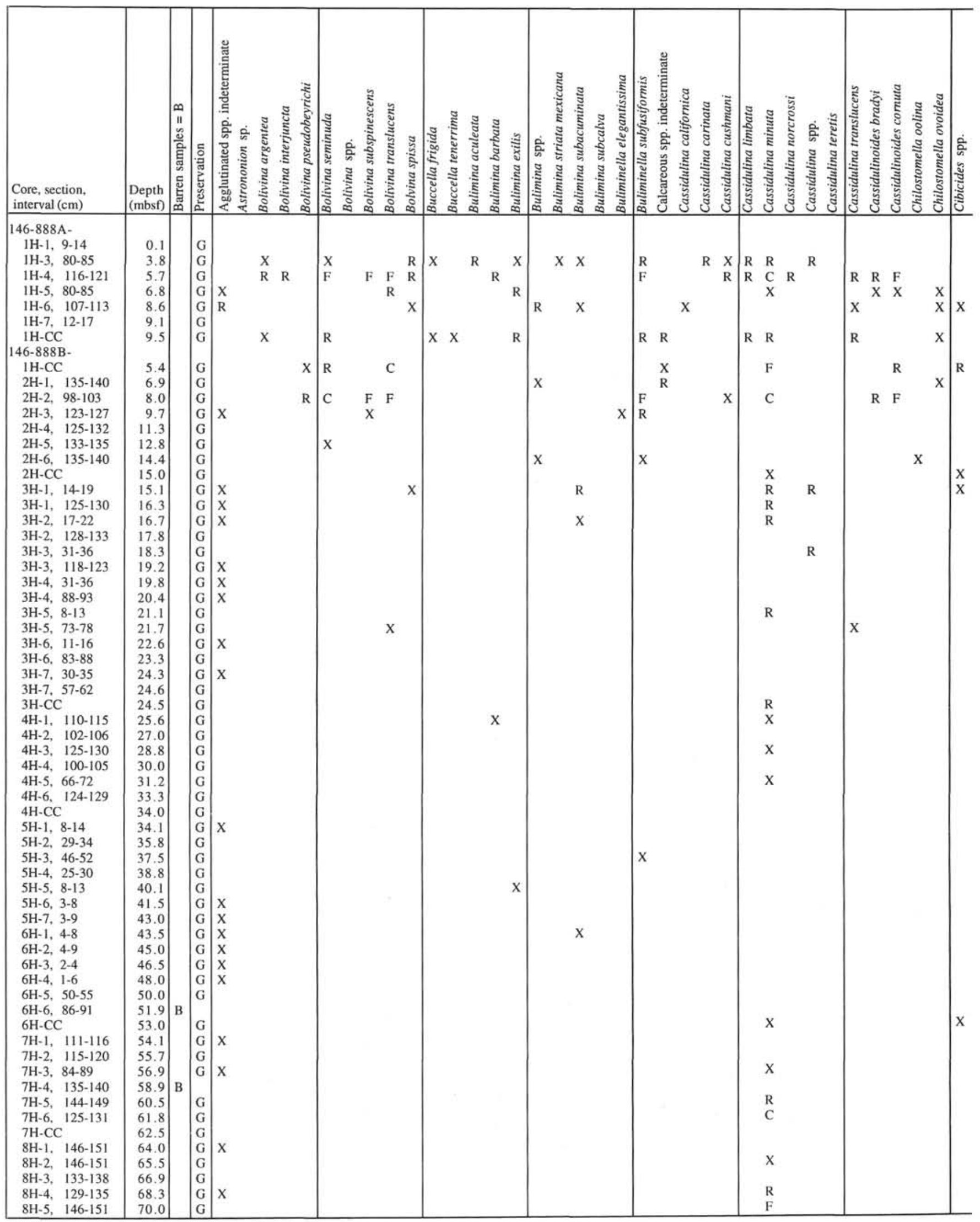

Note: $\mathrm{B}=$ barren samples; see text for explanation of additional abbreviations. 
Table 1 (continued).

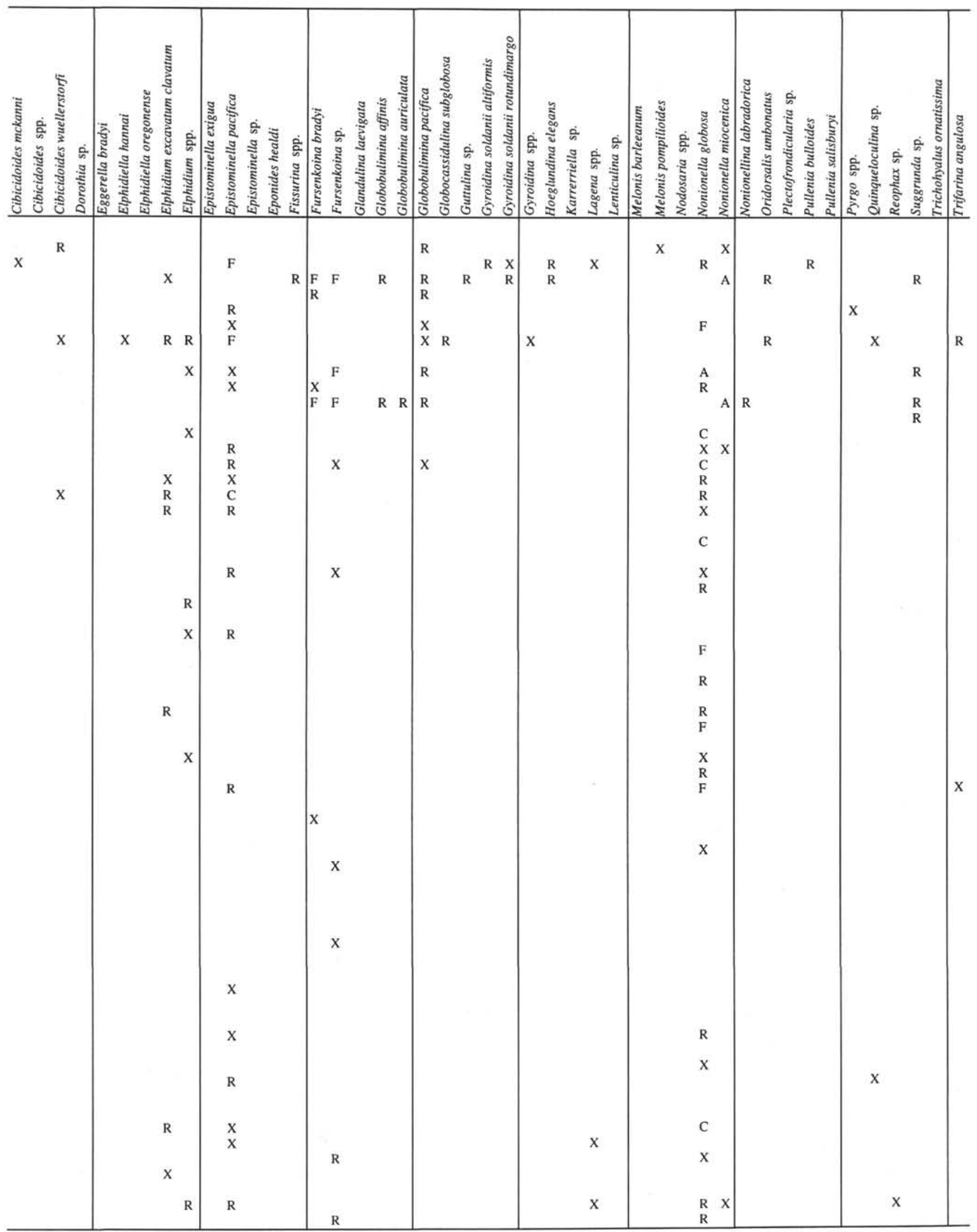


Table 1 (continued).

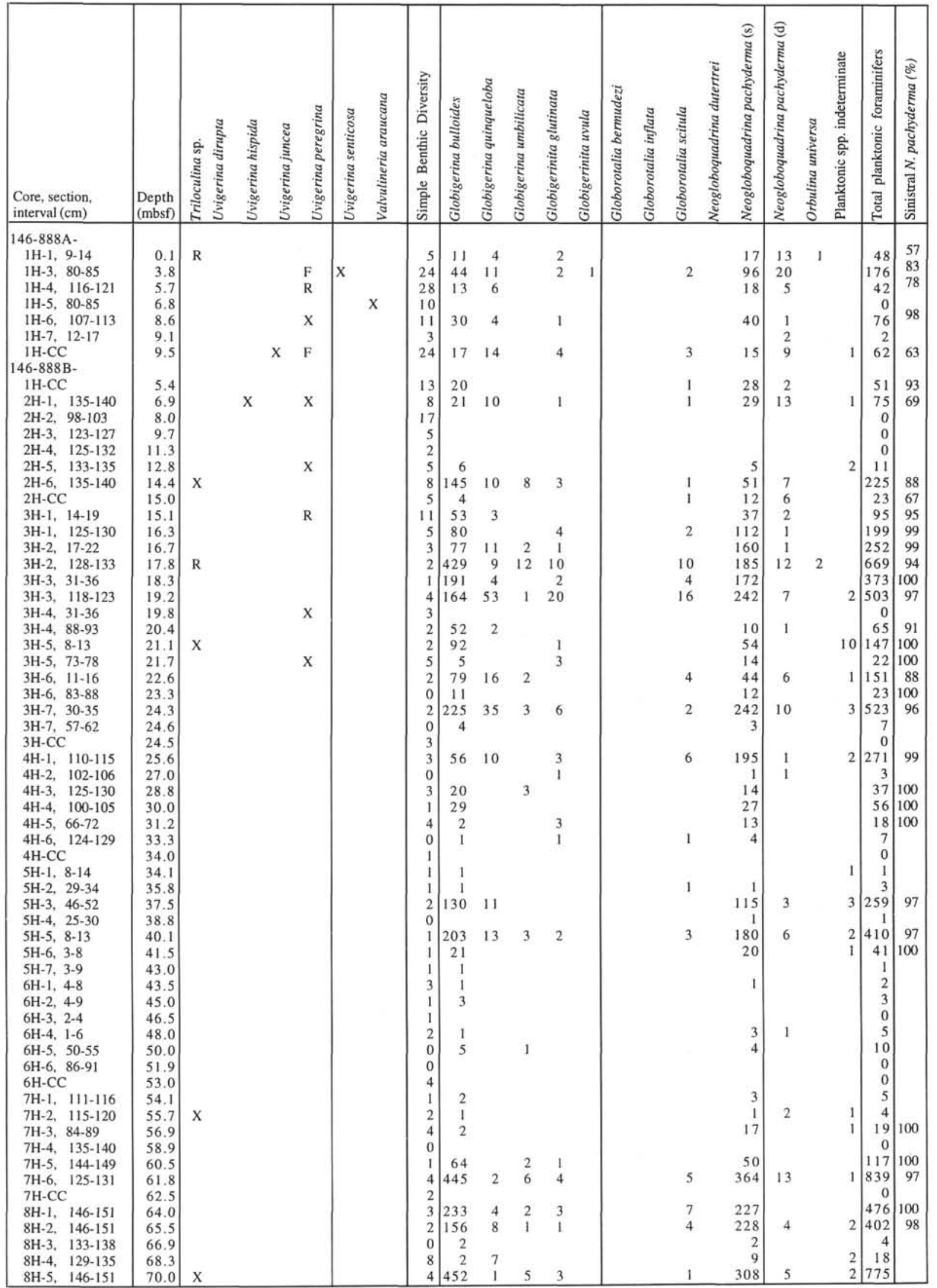


Table 1 (continued).

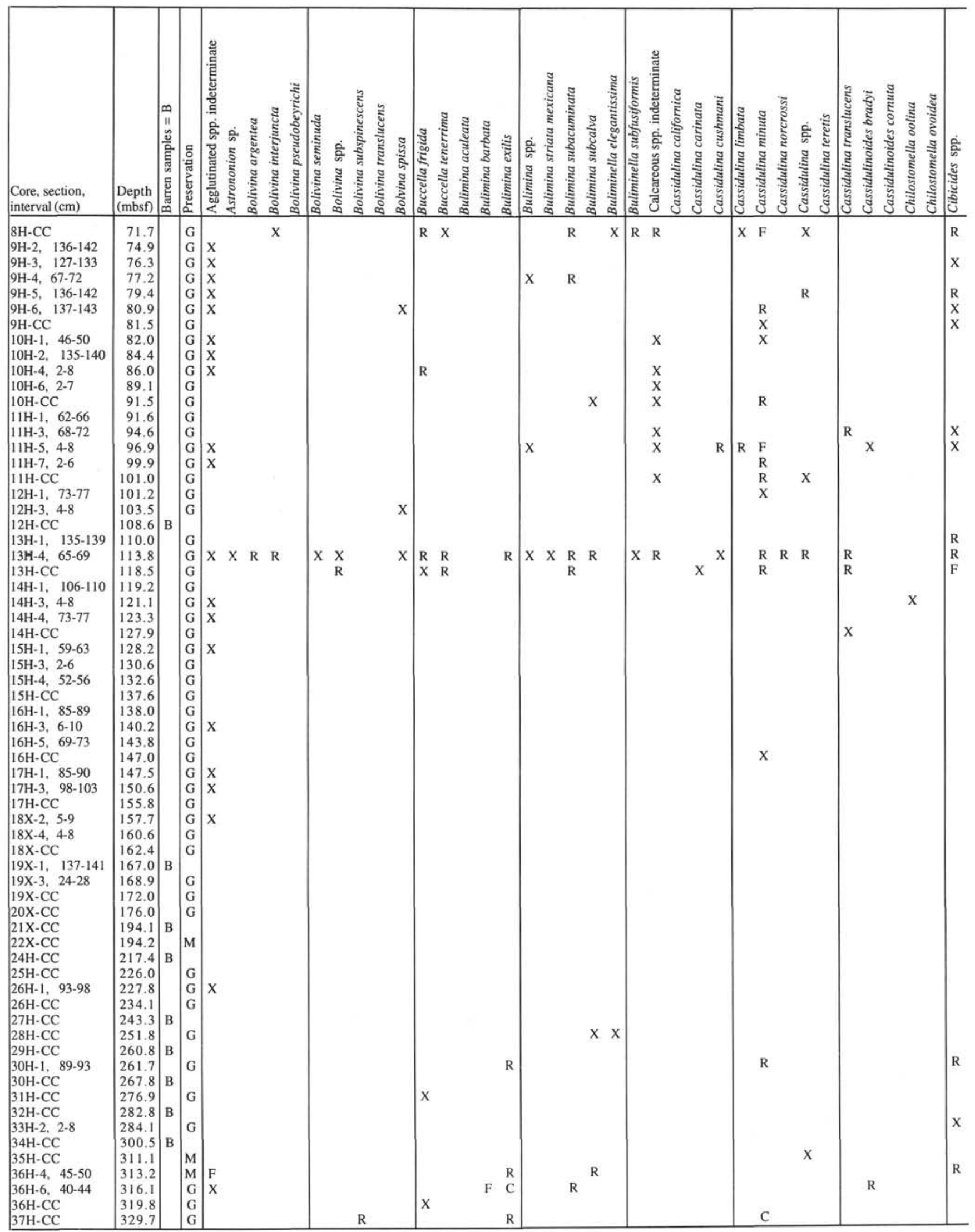


Table 1 (continued).

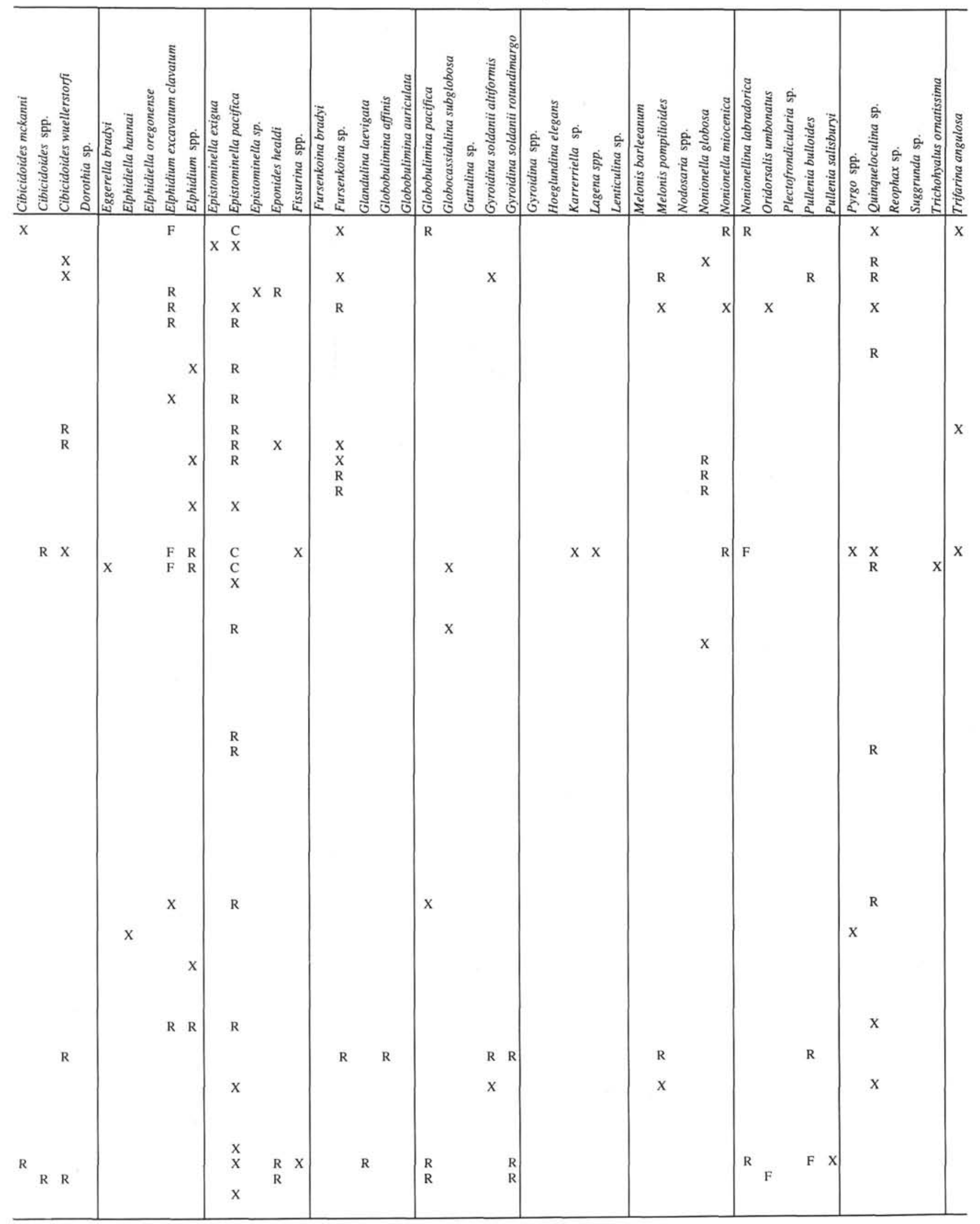


Table 1 (continued).

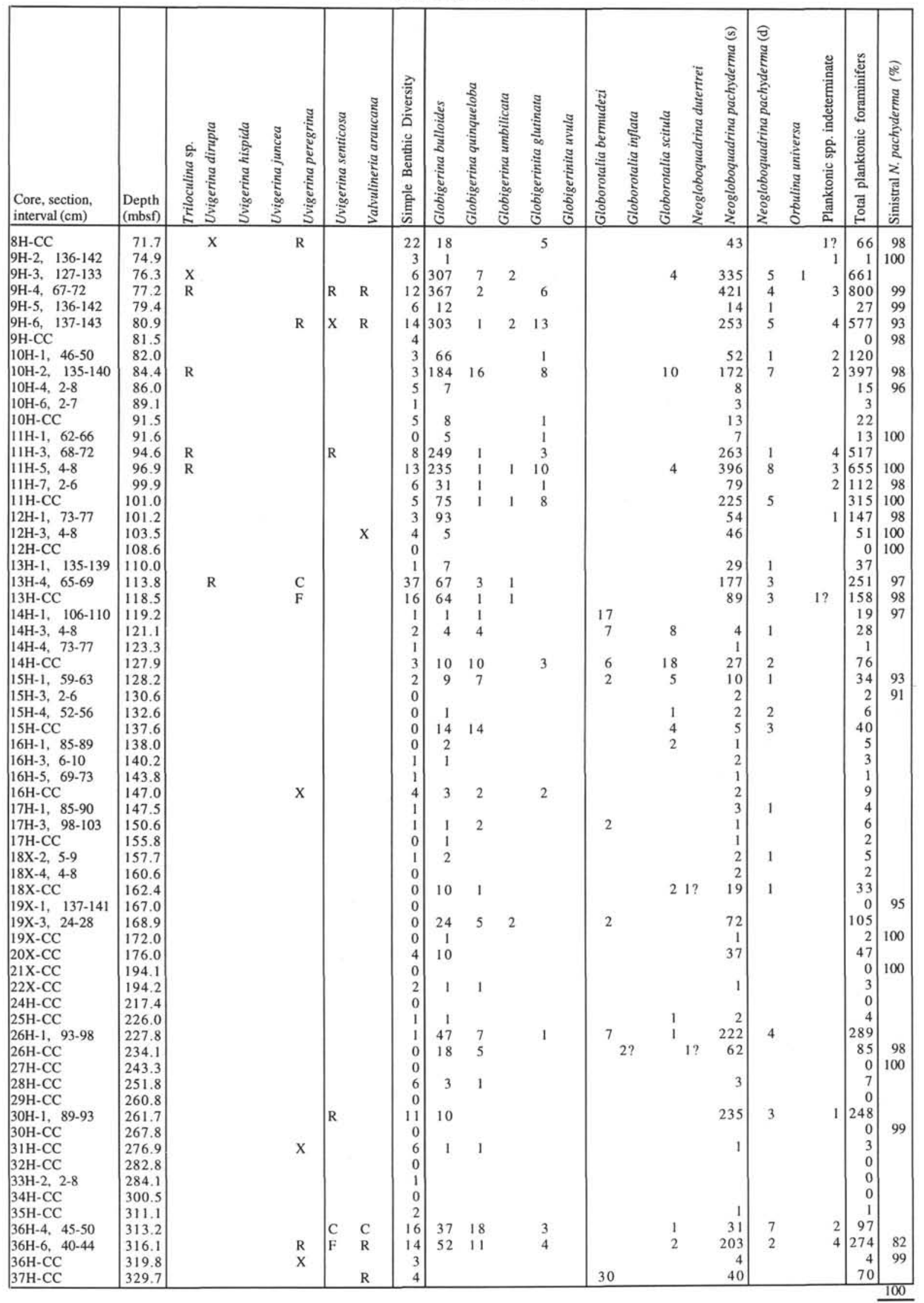


Table 1 (continued).

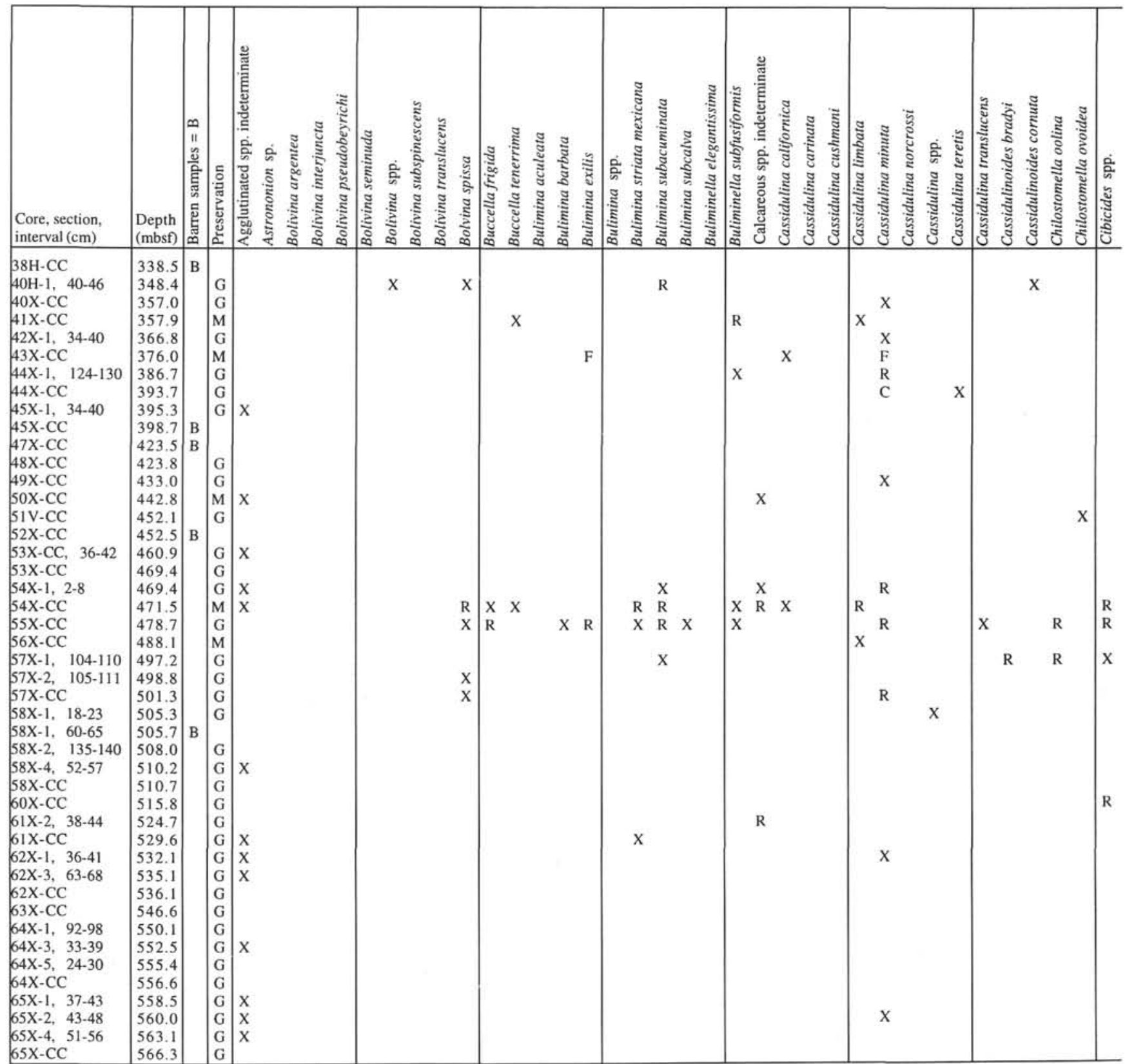

Thirty samples are barren of planktonic foraminifers. The abundance of planktonic foraminifers fluctuates, with the greatest abundances in the top $100 \mathrm{~m}$ of the sequence (Fig. 3). The planktonic assemblages are characterized by significant percentages of Globigerina bulloides, N. pachyderma (sinistral), Globigerina quinqueloba, and Globorotalia scitula, with scattered or rare occurrences of the other taxa listed in Table 1.

Coiling ratios between sinistral and dextral $N$. pachyderma are used in conjunction with radiolarian distributions and paleomagnetic results (Shipboard Scientific Party, 1994a) to provide age determinations for Site 888 . Samples in the top $15 \mathrm{~m}$ of Site 888 contain mixed assemblages of $N$. pachyderma with coiling ratios fluctuating between $57 \%$ to $98 \%$ sinistral (Fig. 3). The mixed coiling, presence of radiolarians of the Botryostrobus aquilonaris Zone of Hays (1970), and normal magnetic polarity indicate an assignment to the CD1-7 coiling dominance zones (Fig. 2), that is, younger than $367 \mathrm{ka}$. Throughout the rest of Hole 888B (from 15 to $567 \mathrm{mbsf}$ ), coiling ratios indicate a dominance of $N$. pachyderma (sinistral). Dominant sinistral $N$. pachyderma, the presence of radiolarians of the B. aquilonaris Zone, and normal magnetic polarity for the sediments (Shipboard Scientific Party, 1994b) give an assignment to the CD8 coiling dominance zone with a maximum age of $600 \mathrm{ka}$.

These age assignments yield quite different bulk accumulation rates for sediments deposited at Site 888 . The upper $15 \mathrm{~m}$ was deposited at a rate of $0.4 \mathrm{~m} / 1000 \mathrm{yr}$, whereas the remainder of the sediments at this site were deposited at rate of $2 \mathrm{~m} / 1000 \mathrm{yr}$. Because the 
Table 1 (continued).

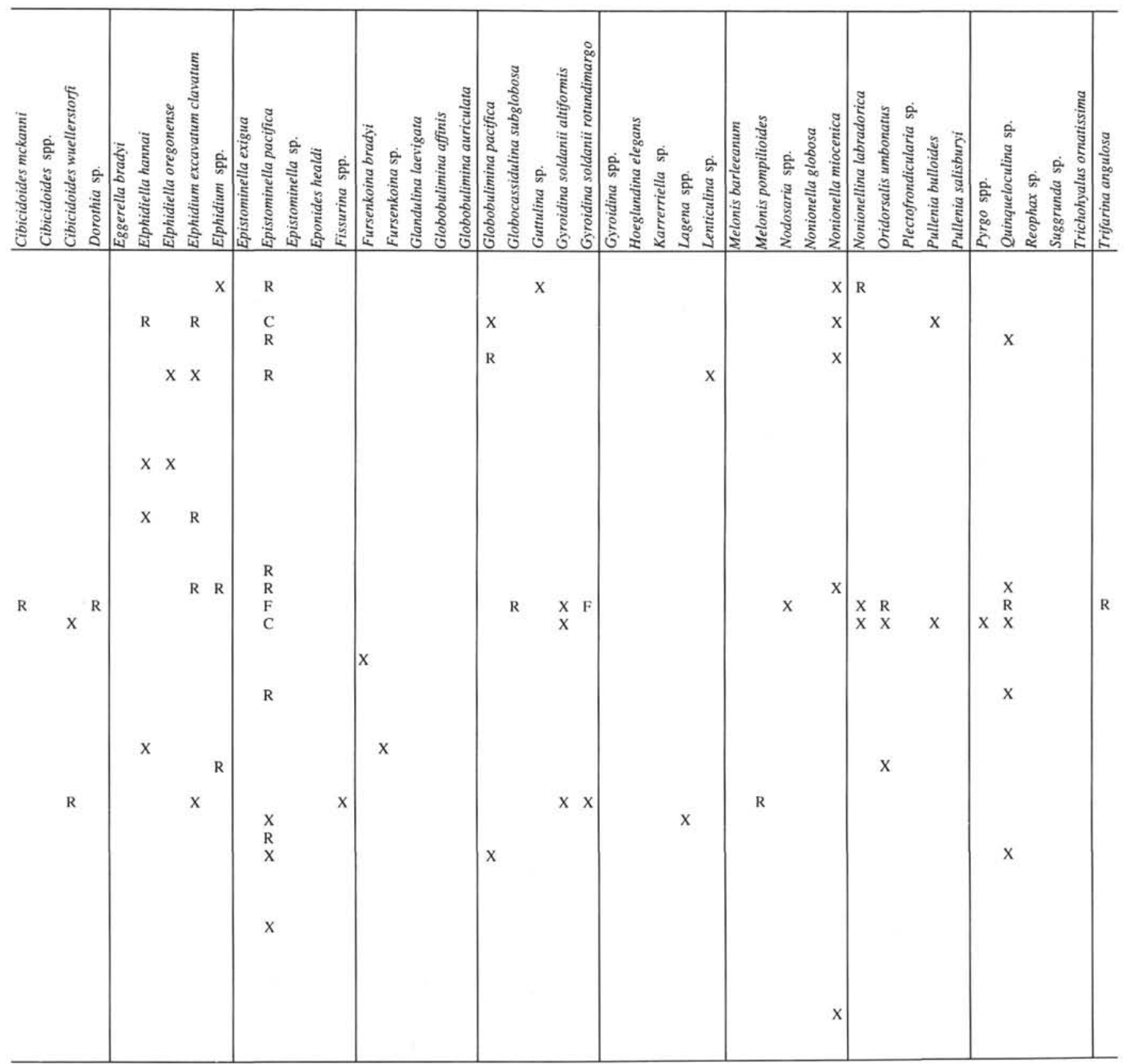

age at the bottom of the cored section is a maximum estimate and rates were not calculated on decompacted sections, these accumulation rates represent minimum values.

Planktonic foraminifers can provide insight into the $\mathbf{Q}$-aternary paleoceanography along the Cascadia margin. Site 888 is located below the divergence of the North Pacific current into the northwardflowing Alaska Current and the southward-flowing California current (Ingle, 1973; Kennett, 1982). Dominantly sinistral populations of $N$. pachyderma from 567 to $15 \mathrm{mbsf}$ indicate cold sea-surface temperatures $\left(\sim 4^{\circ}-12^{\circ} \mathrm{C}\right)$. Planktonic assemblages within this interval (Table 1) are characteristic of Holocene and Pleistocene water masses associated with the Alaska Current system (Ingle, 1973). Sea-surface temperatures in the upper $15 \mathrm{~m}$ at this site fluctuated between cold and cool-temperate $\left(12^{\circ}-20^{\circ} \mathrm{C}\right)$ as indicated by fluctuating abundances of dextral $N$. pachyderma. These cool-temperate faunas are more indicative of water masses associated with the California Current system. The high-frequency changes in coiling ratios are due to regional cooling and warming during the past $367 \mathrm{ka}$ and may also reflect migration of the position of the eastward-flowing North Pacific Current.

\section{Benthic Foraminifers}

Benthic foraminifers are rare to abundant in 134 samples from the sequence cored at Site $888 ; 39$ samples are barren of benthic foraminifers. Eighty-eight species or species groups were identified (Table 1).

The patchy distribution of benthic foraminifers at Site 888 is consistent with the turbidite origin of the sediments (Fig. 3). Sandy samples from this site are barren or contain sparse faunas and finer 
Table 1 (continued).

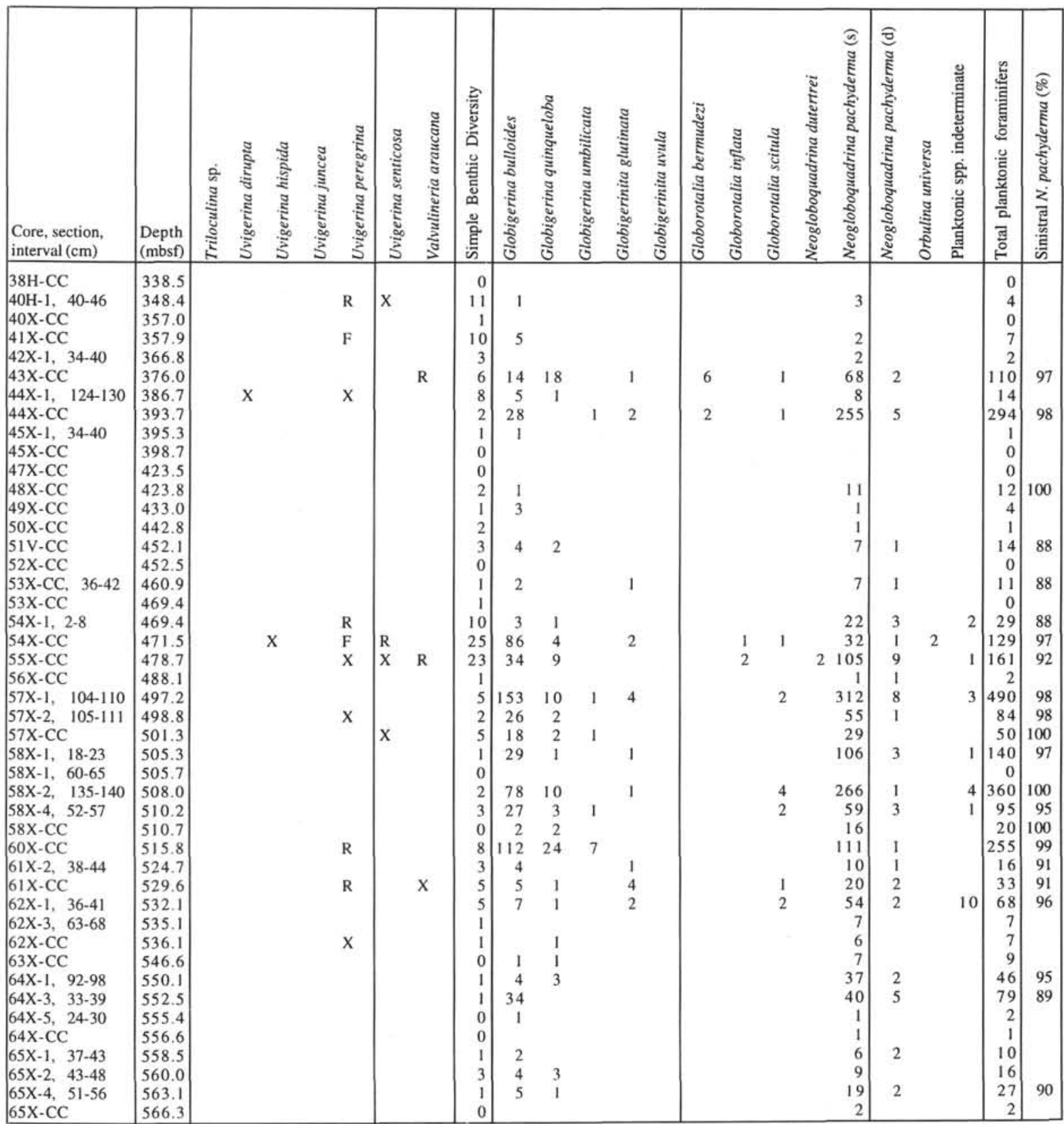

grained lithologies, representing the upper portions of turbidites, contain common to abundant, moderate-diversity foraminiferal faunas. Most samples contain a large component of faunas transported downslope that are mixed with in situ species.

Assemblages of benthic foraminifers can be generalized into two types based on abundances and simple benthic diversity. Simple benthic diversity is the total number of different species or species groups in a sample. The first assemblage type is characterized by low diversity and low abundances; these samples often contain only broken unilocular agglutinated foraminifers. The second type of assemblage consists of common to abundant benthic foraminifers with higher diversities.

Q-mode cluster analysis was performed on samples from Site 888 that contained common to abundant benthic foraminifers in order to classify these samples based on their contained faunas and to further characterize the paleoenvironmental history of this site. Thirty-three species in 39 samples were analyzed using the Cosine Theta similarity measure and an unweighted pair group method of averaging (UWPGMA). For all cluster analyses in this report, estimates of benthic abundances were converted to semiquantitative values $(X=1, R=6$, $\mathrm{F}=20, \mathrm{C}=50, \mathrm{~A}=75$ ). The resulting dendrogram consists of three groups, A, B, and C; group B can be further divided into cluster subgroups B1 and B2 (Fig. 4A). Figure 4B shows the stratigraphic distribution of the samples in each cluster along with the distribution of barren samples and those not included in the cluster analysis.

In order to determine the paleoenvironmental significance of the cluster groups and subgroups, it is necessary to identify the taxa that differentiate each cluster group. A measure called the preference index (PI) (M.B. Lagoe, pers. comm., 1994) is used to emphasize taxa that are more common in samples within the cluster as compared to the total data set. The PI for a taxon is the ratio between the mean abundance of the taxon in the cluster group (MAc) to the mean abun- 
A

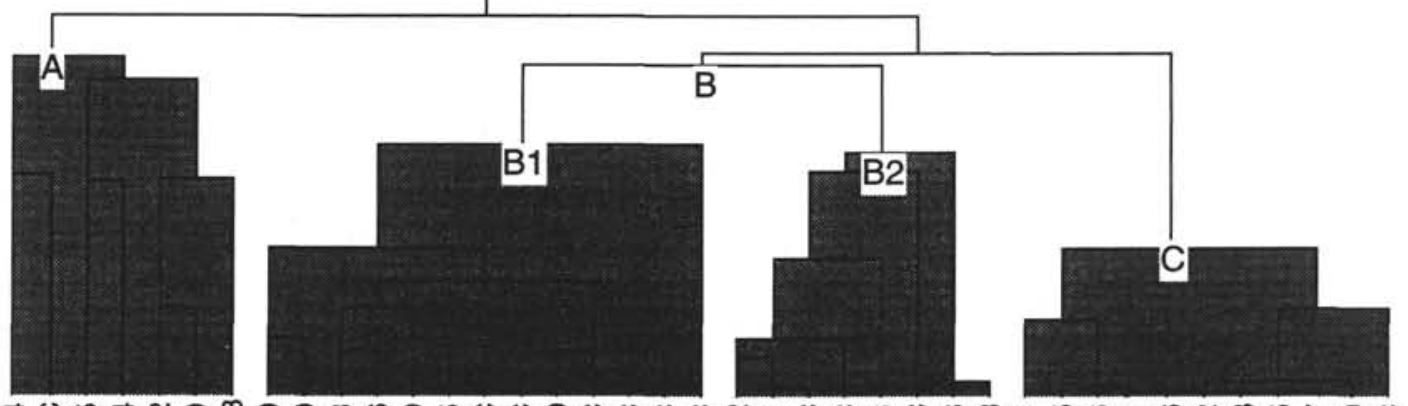

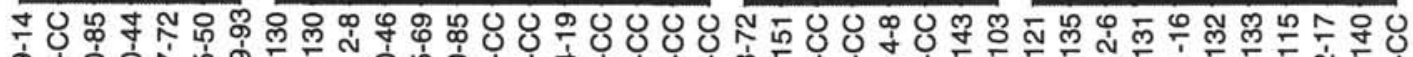

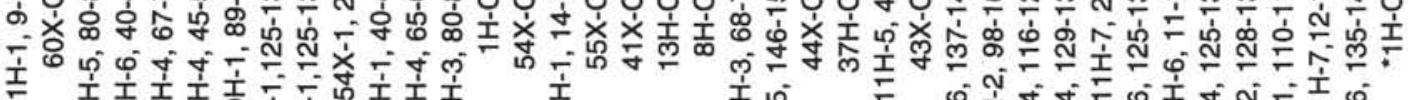

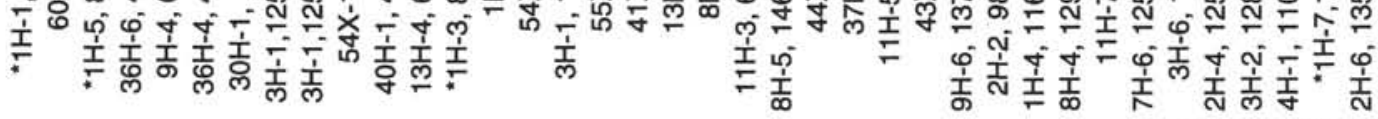

samples from Hole 888A

B

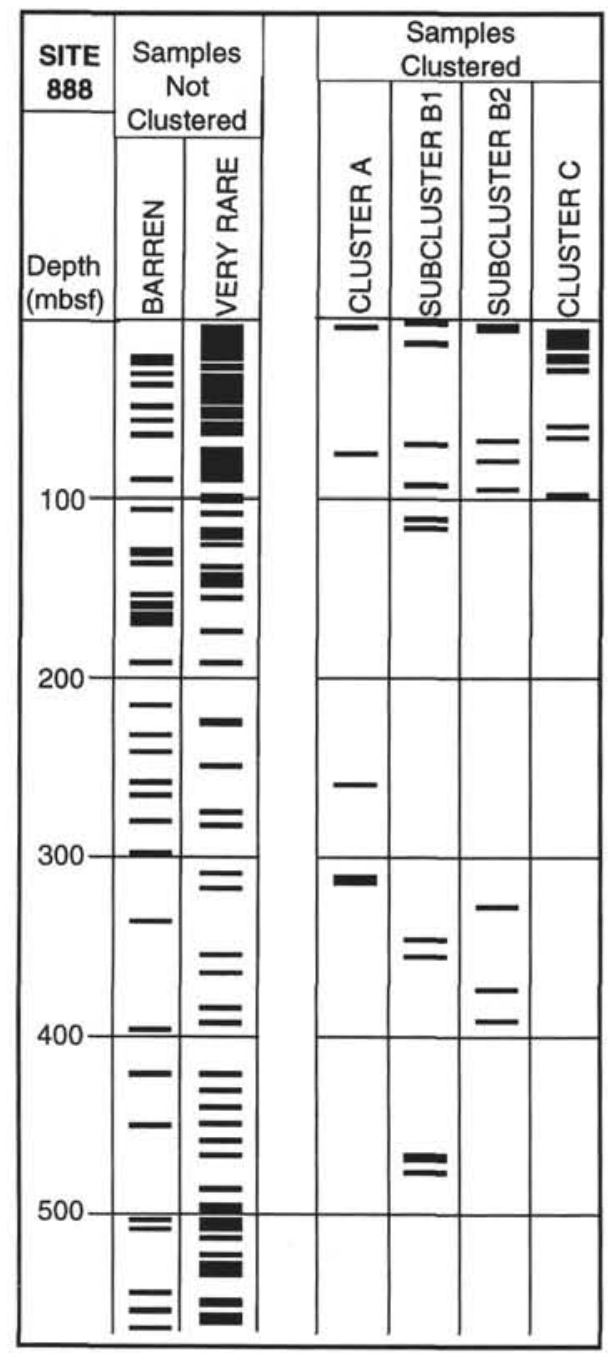

$\mathbf{C}_{6}$

P.I.<smiles></smiles>

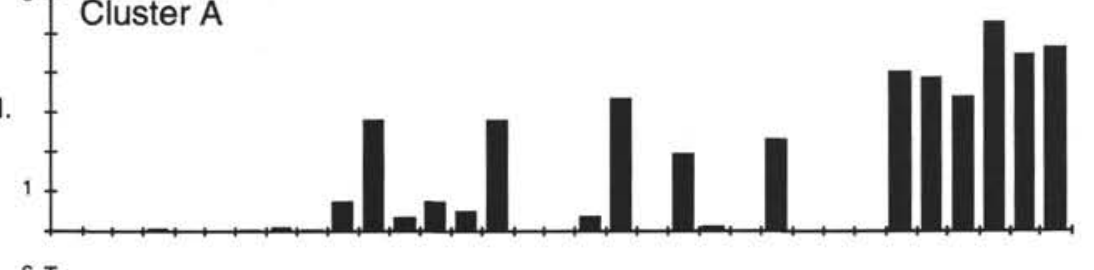

P.I.

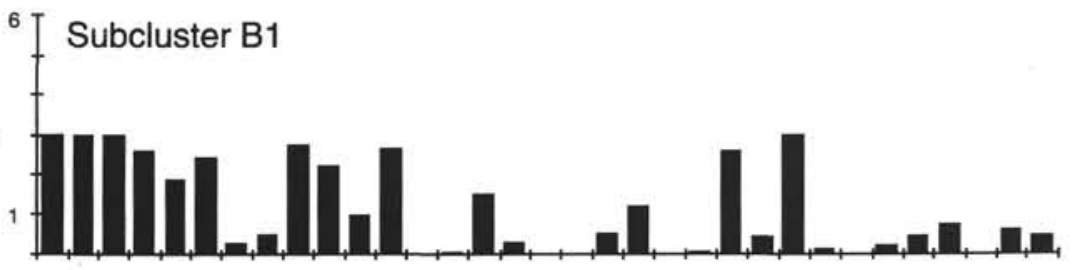

P.I.

${ }^{6}$ I Subcluster B2

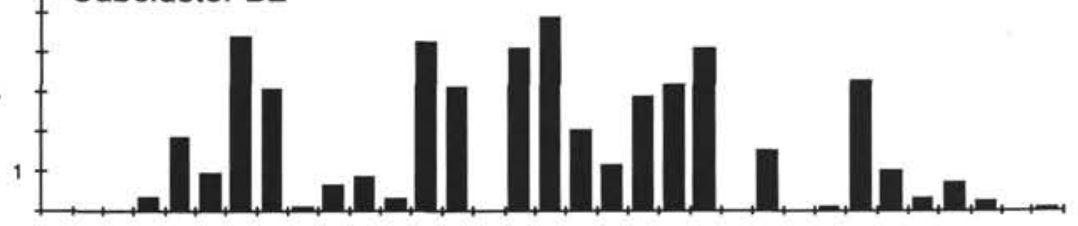

P.I.
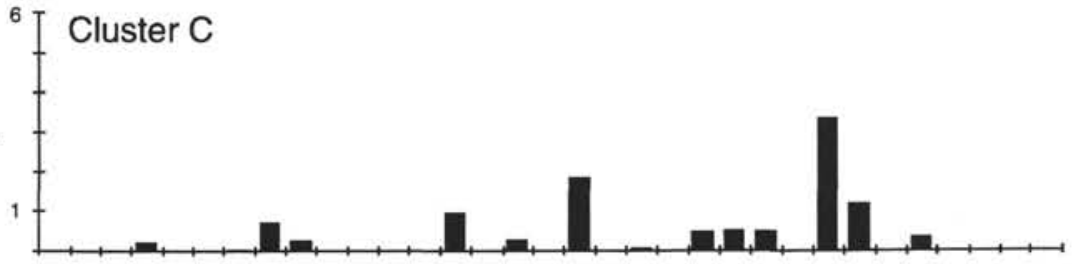

웡 ซ

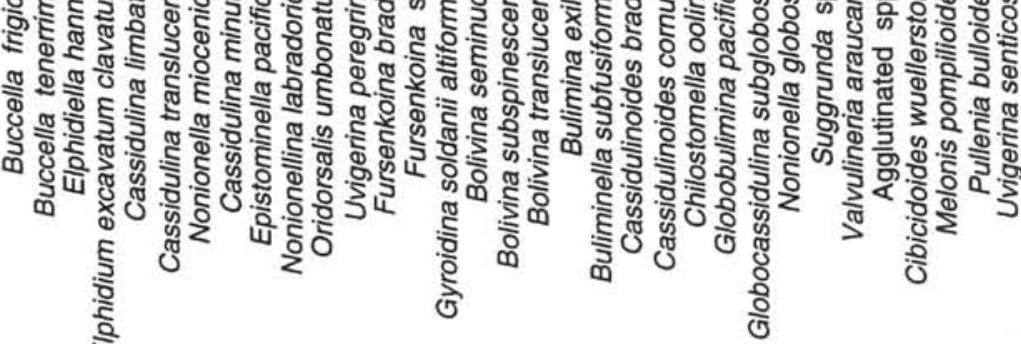

Figure 4. Results of cluster analysis on benthic foraminifers from Site 888. A. Dendrogram. B. Stratigraphic distribution of clustered and nonclustered samples. C. Preference indexes for taxa analyzed by cluster analysis (see text). 
Table 2. Checklist of foraminifers found at Hole 889A.

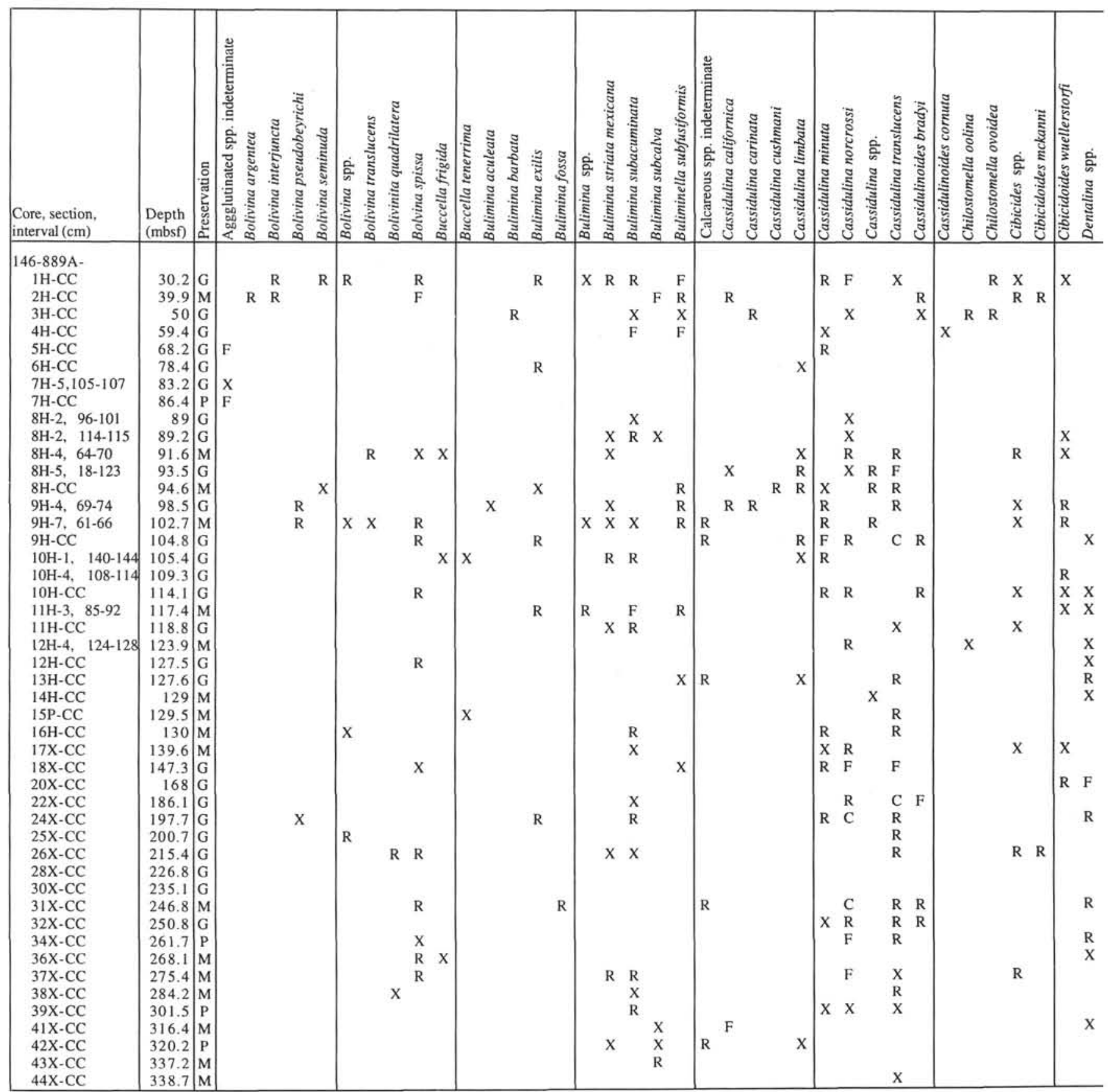

Note: $\mathrm{B}=$ barren samples; see text for explanation of additional abbreviations.

dance of the taxon in all the samples (MAt), or PI = MAc/MAt. PI values greater than 1.0 show that the taxon is more common in samples within the cluster than in the total data set. PI values of less than 1.0 indicate that the taxon is more common in samples of other cluster groups. A PI value of 1.0 indicates that the taxon has the same average abundance in samples within the cluster group as in the overall data set.

Each cluster group or subgroup can be differentiated by the taxa with the highest PIs. The PI for the taxa in all the cluster groups and subgroups is illustrated graphically in Figure 4C. Once the taxa that are used to differentiate the clusters are known, the paleoenviron- mental significance of the dominant assemblages within the clusters can be inferred.

Cluster group A consists of samples with high PIs for Melonis pompilioides, Uvigerina senticosa, Pullenia bulloides, Cibicidoides wuellerstorfi, Gyroidina soldanii altiformis, Bulimina exilis, Oridorsalis umbonatus, and Cassidulinoides bradyi. This fauna represents deposition within lower middle bathyal to lower bathyal environments.

Samples in subgroup B1 contain a mixture of taxa representing different environments. Buccella frigida, B. tenerrima, Elphidiella hannai, and Elphidium excavatum clavatum are indicative of an inner 
Table 2 (continued).

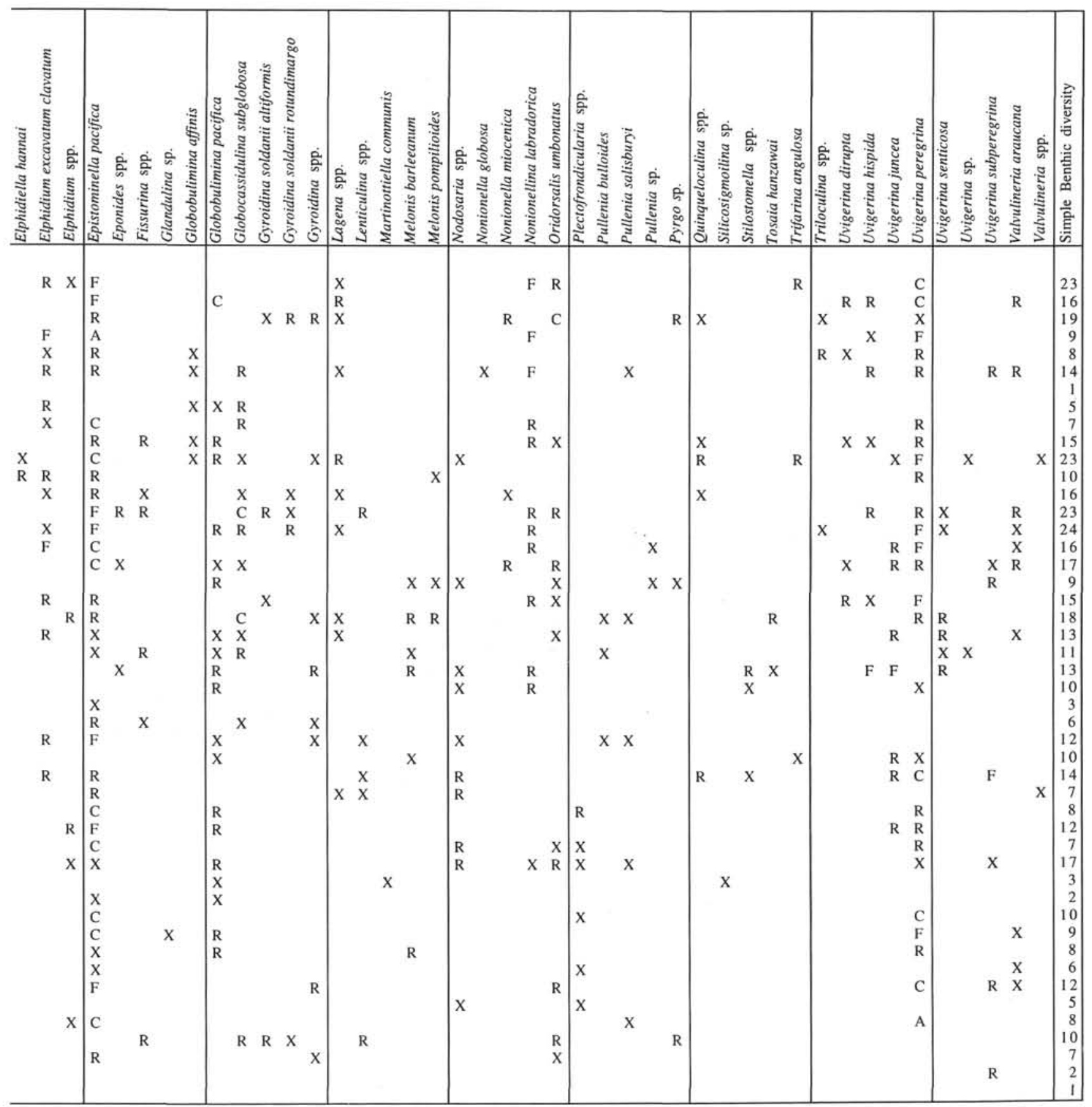

neritic environment. Chilostomella oolina, Globocassidulina subglobosa, Gyroidina soldanii altiformis, Nonionellina labradorica, and Uvigerina peregrina are indicative of upper bathyal environments. Epistominella pacifica represents deposition in upper middle bathyal environment. This mixing of neritic through bathyal biofacies, from downslope transport, is consistent with the interpretation of turbidites (Shipboard Scientific Party, 1994b) for these sediments.

Subgroup B2 consists of samples with diverse assemblages of taxa that are generally associated with the low-oxygen conditions in the eastern Pacific Ocean (Ingle, 1980). These well-preserved, thinshelled taxa are Bolivina subspinescens, Fursenkoina bradyi, B. seminuda, B. translucens, Buliminella subfusiformis, Cassidulinoides bradyi, C. cornuta, and Suggrunda spp. Also present in samples within subgroup B2 are Nonionella miocenica, Cassidulina minuta, and $C$. limbata suggesting downslope transport of neritic taxa.

Samples in cluster $\mathrm{C}$ contain low diversity assemblages composed of Bolivina translucens, Nonionella globosa, and Suggrunda spp. This assemblage is also indicative of low-oxygen conditions or associated high-productivity surface waters.

The thin-shelled, low-oxygen indicators in samples from subcluster B2 and cluster C are abundant and well preserved. Larger radiolarians and diatoms are abundant in the washed foraminiferal residues from these samples as well, suggesting original deposition beneath high-productivity surface waters in a middle bathyal environment. Either these faunas are in situ or have been transported downslope. The relatively low amount of organic carbon $(<0.8 \mathrm{wt} \%$, Shipboard 
Table 2 (continued).

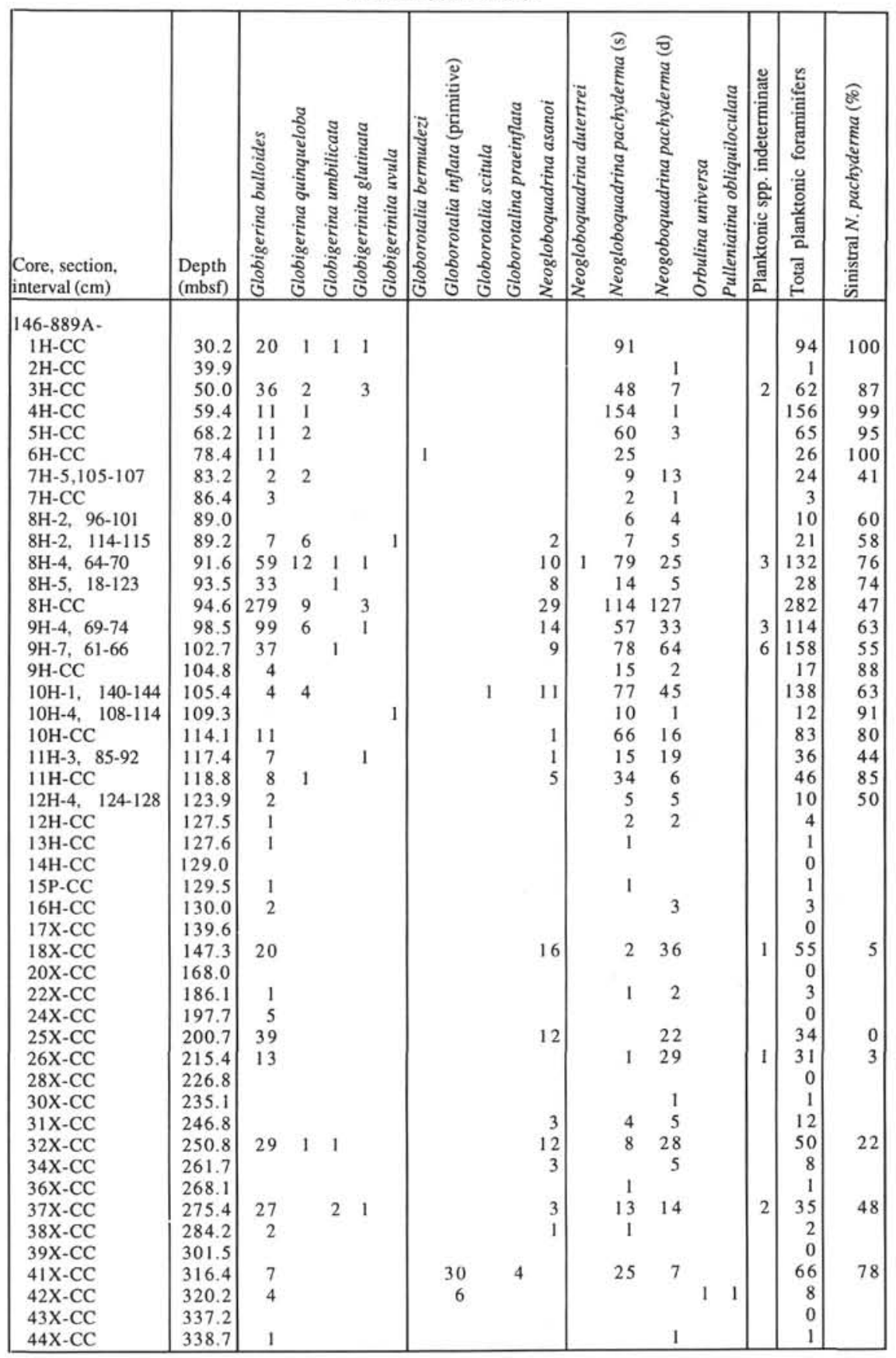

Scientific Party, 1994b) could argue against preservation of these faunas beneath a high-productivity zone. It is likely that these delicate faunas and the associated siliceous assemblages were transported downslope rapidly from a benthic environment with low oxygen conditions.

Sediments at Site 888 contain a mixture of faunas from neritic through lower bathyal environments. Lower bathyal indicators, which are the deepest dwelling forms at this site, are rare and are scattered throughout the sequence. These mixed faunas, with a dominance of shallower taxa and rarity of in situ faunas, are typical of turbidites. Although lower bathyal indicators are rare, a lower bathyal interpretation is given for this entire site (Fig. 3). This interpretation is further constrained by the present position of this site in a lower bathyal environment on the undeformed abyssal plain portion of the Juan de Fuca Plate.

\section{Sites $\mathbf{8 8 9 / 8 9 0}$}

Sites $889\left(48^{\circ} 41.958^{\prime} \mathrm{N}, 126^{\circ} 52.098^{\prime} \mathrm{W}\right)$ and $890\left(48^{\circ} 39.750 \mathrm{~N}\right.$, $126^{\circ} 52.890$ W) are located within the accretionary wedge on the continental slope off Vancouver Island in water depths of 1315 and 1326 mbsl, respectively (Fig. 1). Coring at Site 889 recovered almost 387 $\mathrm{m}$ of interslope basin sediment and underlying, deformed sediments of the accretionary wedge. The upper $50 \mathrm{~m}$ of undeformed interslope basin sediment was recovered at Site 890 .

Three lithostratigraphic units are recognized at Sites 889 and 890 . Lithostratigraphic Unit I (0-128.0 mbsf) includes clayey silts, fine sands, and diagenetic carbonates. This unit is subdivided into two units, Subunits IA and IB, with Subunit IB distinguished by mud clasts and tilted beds. Unit II (128.0-301.5 mbsf) is similar in composition to Unit I, but is finer grained, more consolidated, and highly 


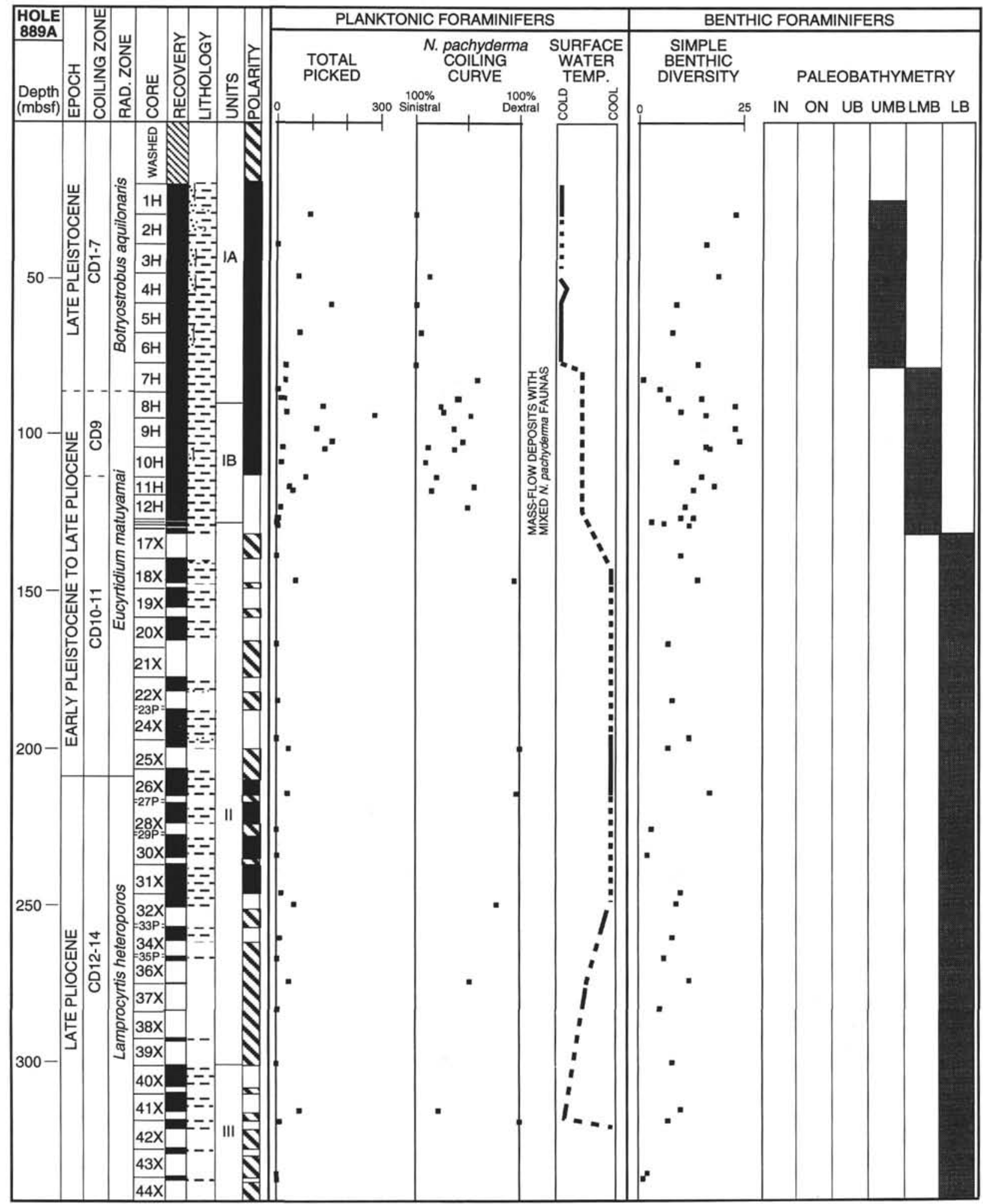

Figure 5. Summary of age zonation, core recovery, lithology, magnetic polarity, foraminiferal distributions, inferred sea-surface temperatures, and paleobathymetry at Site 889 . Key to lithologic symbols: thin dashed pattern = silty clay and clayey silt; coarse stipple = silty sand and sandy silt. Key to polarity units: black = normal polarity; white $=$ reversed polarity; diagonal $=$ undetermined. See Shipboard Scientific Party (1994c) for radiolarian zonations and more detailed lithologic and paleomagnetic information. 
fractured and brecciated. Lithostratigraphic Unit III (301.5-386.5 mbsf) is similar to Unit II and is marked by an increase in the amount of glauconite and related minerals.

Lithostratigraphic Unit I consists of interslope basin sediments that are hemipelagites, turbidites, and mass-flow deposits (Subunit IB). The sedimentary characteristics of Units II and III are not diagnostic of a particular sedimentary environment but suggest deposition by distal, low-energy turbidity currents. It is postulated that sediments in Units II and III may represent deposition in an abyssal plain environment (Shipboard Scientific Party, 1994c).

\section{Hole 889A}

\section{Planktonic Foraminifers}

Poorly to well-preserved upper Pliocene through Quaternary planktonic foraminifers are rare to abundant in 39 samples from Hole 889A (Table 2). Six samples are barren of planktonic foraminifers.

Table 3. Checklist of foraminifers found at Hole 889B.

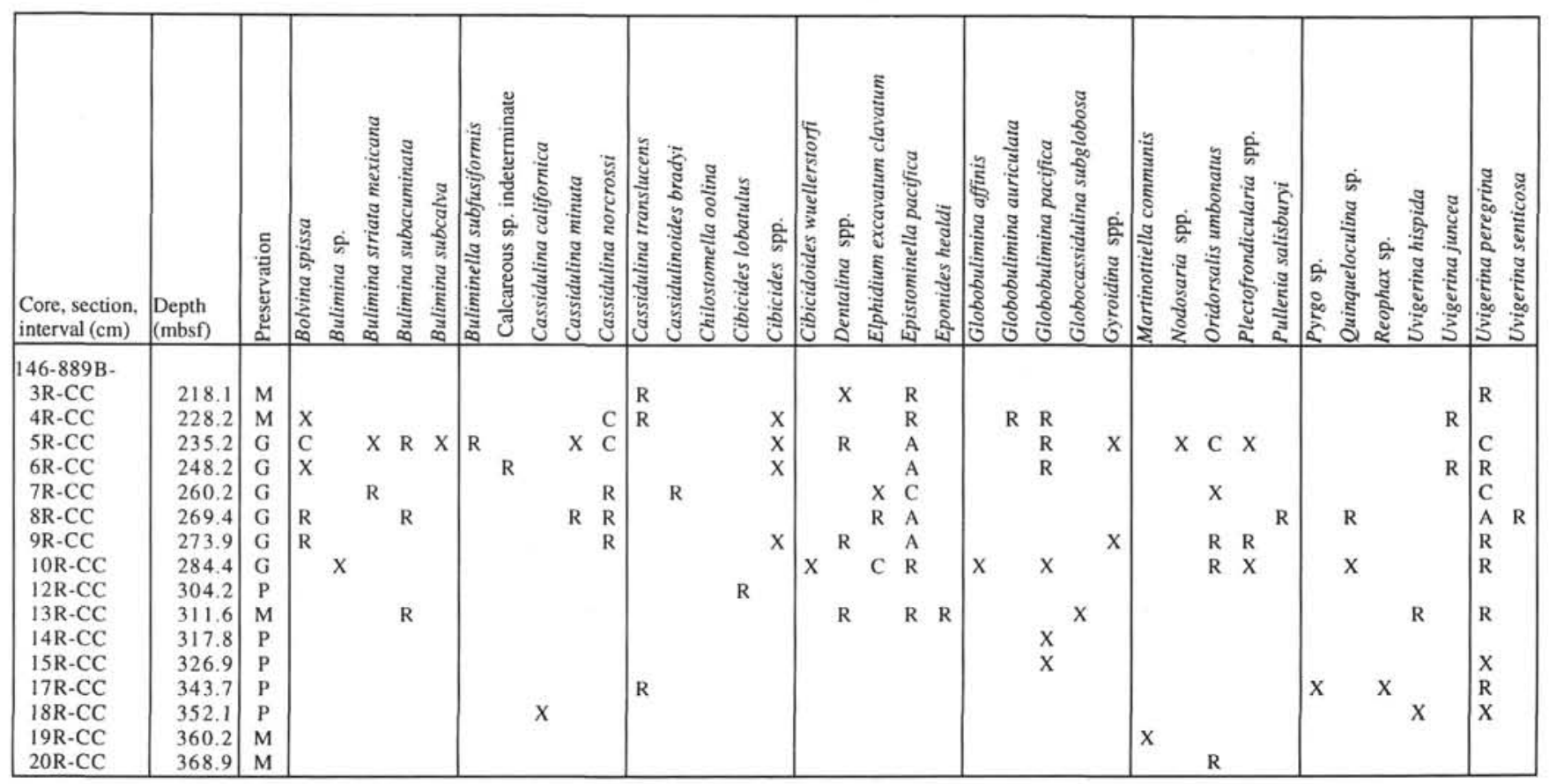

Note: $\mathrm{B}=$ barren samples; see text for explanation of additional abbreviations.

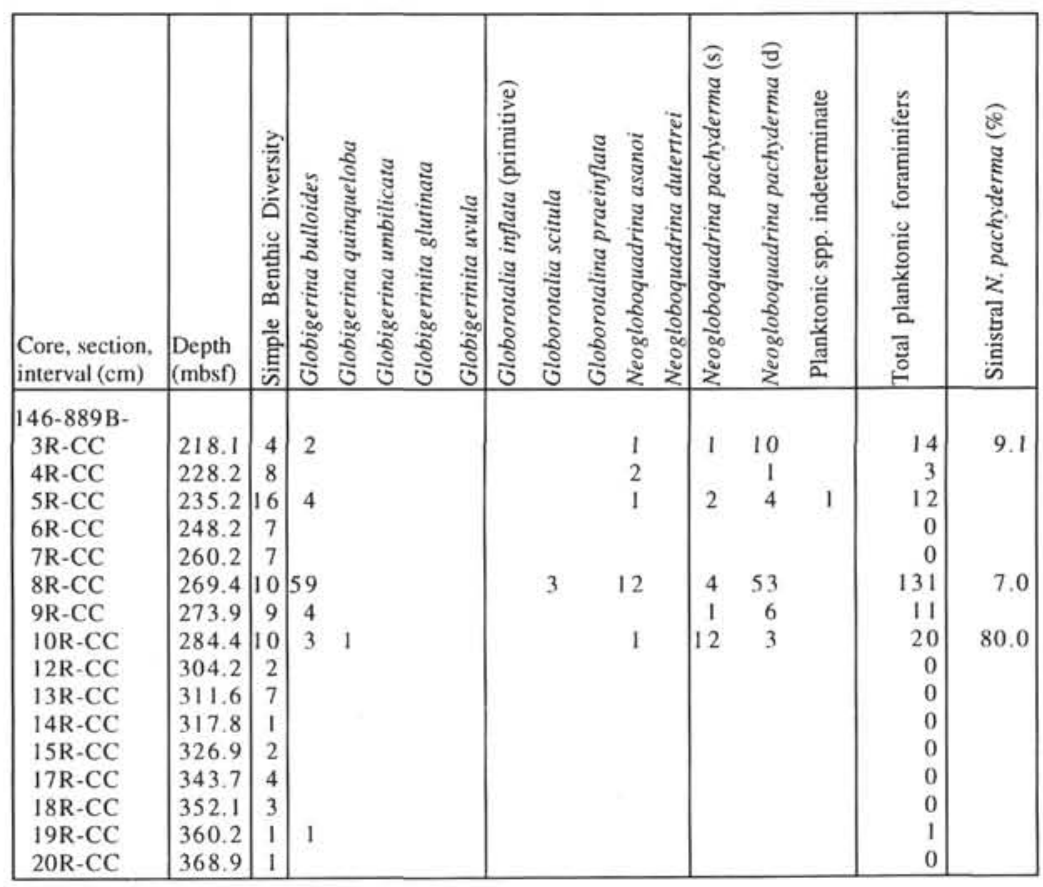


Samples in the interval from 20 to 86.4 mbsf are dominated by few to common $G$. bulloides and N. pachyderma (sinistral), and rare to few $G$. quinqueloba and $N$. pachyderma (dextral). Sediments in this interval have normal magnetic polarity, contain radiolarians of the $B$. aquilonaris Zone, and have dominantly sinistrally coiled $N$. pachyderma, yielding an age assignment in the CD1-7 coiling zone (Fig. 5).

A hiatus is recognized on the basis of radiolarian biostratigraphy at about 88 mbsf (Shipboard Scientific Party, 1994c). At 88 mbsf upper Pleistocene strata of the B. aquilonaris Zone occur above uppermost Pliocene/lower Pleistocene strata belonging to the Eucyrtidium matuyamai Zone of Hays (1970). The absence of the Stylatractus universus Zone (Hays, 1970) infers a hiatus, lasting about $0.6 \mathrm{~m} . \mathrm{y}$.

The interval from 89.2 to 119 mbsf contains rare to abundant $G$. bulloides, $N$. pachyderma (sinistral), and $N$. pachyderma (dextral) with rare to common occurrences of $N$. asanoi and rare to few $G$. quinqueloba. Also present in this interval are the uppermost Pliocene/lower Pleistocene radiolarian, E. matuyamai, and lower Pliocene radiolarians. It is difficult to determine the age of this interval because of the nature of the sediments (mass-flow deposits) and the association of E. matuyamai, $N$. asanoi, mixed sinistral and dextral $N$. pachyderma, and lower Pliocene radiolarians. The first occurrence of E. matuyamai and the last occurrence of $N$. asanoi are at 1.9 Ma according to the time scale of Cande and Kent (1992) (Shipboard Scientific Party, 1994c). It is unlikely that the sediments within the interval from 89.2 to 119.0 were deposited within the overlap in ranges of these taxa because of the presence of mixed populations of dextral and sinistral $N$. pachyderma. The short overlap in ranges of $E$. matuyamai and $N$. asanoi occurs within a zone of sinistrally coiled $N$. pachyderma, not one with mixed coiling. Therefore, based on the occurrence of E. matuyamai, the mixed sinistral and dextral $N$. pachyderma assemblages, and a normal paleomagnetic signature, the interval from 89.2 to $119.0 \mathrm{mbsf}$ is assigned to the CD9 coiling zone. Although they are common and well preserved, specimens of $N$. asanoi within this interval are considered to be reworked.

Rare to few, poorly to well-preserved $G$. bulloides, $N$. pachyder$m a$ (sinistral and dextral), and $N$. asanoi occur sporadically in the interval from 119 to 338.7 mbsf. Within this interval Sample 146889 A-41X-CC contains a mixture of Globorotalia inflata primitive form and $G$. inflata praeinflata (Table 2). The first occurrence of $G$. inflata praeinflata, a transitional form between the $G$. inflata primitive and $G$. inflata modern forms, coincides with the end of the Gauss Chron (Keller, 1980), which makes this sample no older than $2.6 \mathrm{Ma}$ following the Cande and Kent (1992) time scale. This interval is assigned to the CD12-CD14 zone based on the presence of N. asanoi, $N$. pachyderma (sinistral and dextral), G. inflata primitive, and $G$. inflata praeinflata.

Several paleoclimatic intervals can be inferred from coiling ratios at Hole $889 \mathrm{~A}$. From the sea floor to $78.4 \mathrm{mbsf}$, dominantly sinistrally coiled $N$. pachyderma indicate cold surface waters. The paleoclimatic signal in the interval from 78.4 to 119 mbsf is difficult to interpret because of resedimentation; however, the mixed sinistral and dextral assemblages suggest cold to cool temperate surface waters. There is a general up hole increase in the number of dextral $N$. pachyderma within the interval from 123.9 to $345.8 \mathrm{mbsf}$, indicating a warming of surface waters during the late Pliocene to early Pleistocene. This warming trend has been documented throughout the eastern Pacific (Lagoe and Thompson, 1988).

\section{Benthic Foraminifers}

Moderately to well-preserved benthic foraminifers are rare to abundant in all samples examined from Hole 889A (Table 2). The benthic assemblages in this hole are dominated by Epistominella pacifica, Uvigerina peregrina, Cassidulina translucens, $C$. norcrossi, Globobulimina pacifica, Bulimina subacuminata, and Bolivina spissa. A Q-mode cluster analysis was performed, but no significant cluster groups were formed due to the homogeneous nature of the faunas at this hole. There are, however, some general differences in the faunas among the three lithostratigraphic units recognized at this hole. Buliminella subfusiformis, Elphidium excavatum clavatum, Globocassidulina subglobosa, Oridorsalis umbonatus, and Nonionellina labradorica are rare to few in lithostratigraphic Unit I. Subunit IB contains the lower middle bathyal indices Melonis barleeanum, Gyroidina soldanii rotundimargo, and U. hispida, and also rare, often broken specimens of Cibicidoides wuellerstorfi, $U$. senticosa, and M. pompilioides. Broken specimens of Plectofrondicularia sp. are only found in lithostratigraphic Unit II. C. wuellerstorfi, Martinottiella communis, Silicosigmoilina sp., and Stilostomella sp. are also present in Unit II. Lithostratigraphic Unit III contains rare, low diversity calcareous faunas.

Sediments in Subunit IA contain benthic assemblages indicative of an upper middle bathyal environment, similar to present water depths at this site. Assemblages in Subunit IB probably represent a mixture of faunas caused by slumping of older sediments containing lower bathyal faunas into a lower middle bathyal environment. Although lower bathyal indicators are only rare in Units II and III, these distal turbidites were probably formed in a lower bathyal environment (Fig. 5). Thus, there has been a decrease in paleobathymetry of sediments at Site 889 through time as these sediments were uplifted while being accreted to the margin.

\section{Hole 889B}

\section{Planktonic Foraminifers}

Of the 16 samples examined for planktonic foraminifers in Hole $889 \mathrm{~B}$, only seven contain planktonic foraminifers. Planktonic foraminifers are present, in low abundances from 225.3 to $289.3 \mathrm{mbsf}$, but virtually absent from $301.7 \mathrm{mbsf}$ to the bottom of Hole $889 \mathrm{~B}$ (Table 3). Where present, planktonic assemblages consist of $N$. pachyderma (dextral and sinistral), G. bulloides, and N. asanoi. Dextral forms of $N$. pachyderma are more common than sinistral forms except in Sample 146-889B-10R-CC, suggesting cool temperate surface waters. A late Pliocene age is indicated by this assemblage.

\section{Benthic Foraminifers}

Benthic foraminifers are rare to abundant in all samples examined from Hole $889 \mathrm{~B}$. Low diversity benthic foraminifers are rare to abundant in the interval from 225.3 to 289.3 mbsf, where planktonic foraminifers are also most common. Benthic assemblages are dominated by Epistominella pacifica, Uvigerina peregrina, Bolivina spissa, Cassidulina norcrossi, and Oridorsalis umbonatus. The neritic species Elphidium excavatum clavatum is common in Sample 146889B-10R-CC, indicating downslope transport from neritic waters. Samples from $307.1 \mathrm{mbsf}$ to the bottom of the hole contain very rare or rare specimens of several different species. An upper middle bathyal environment or possibly deeper is suggested for this section.

\section{Net Uplift at Site 889}

Benthic foraminifers indicate shallowing through time at Site 889 (Fig. 5). Although changes in paleoenvironments may reflect either tectonic uplift or water-mass fluctuations, it is most likely, given the structural setting on the accretionary wedge, that the decrease in paleobathymetry through time at Site 889 is due to uplift by accretionary processes. Paleoenvironmental analysis can provide constraints on the amount of net uplift at Site 889. The range of net uplift can be calculated by subtracting the present-day water depth of the site from the upper and lower ranges of the interpreted paleoenvironmental zone for each interval. The present water depth at Site 889 is approximately $1315 \mathrm{mbsl}$. Therefore, the lower bathyal sediments in Units II and III have been uplifted at least $700 \mathrm{~m}$ and possibly as much as $2700 \mathrm{~m}$. Lower middle bathyal sediments within Subunit IB have un- 
Table 4. Checklist of foraminifers found at Site 891.

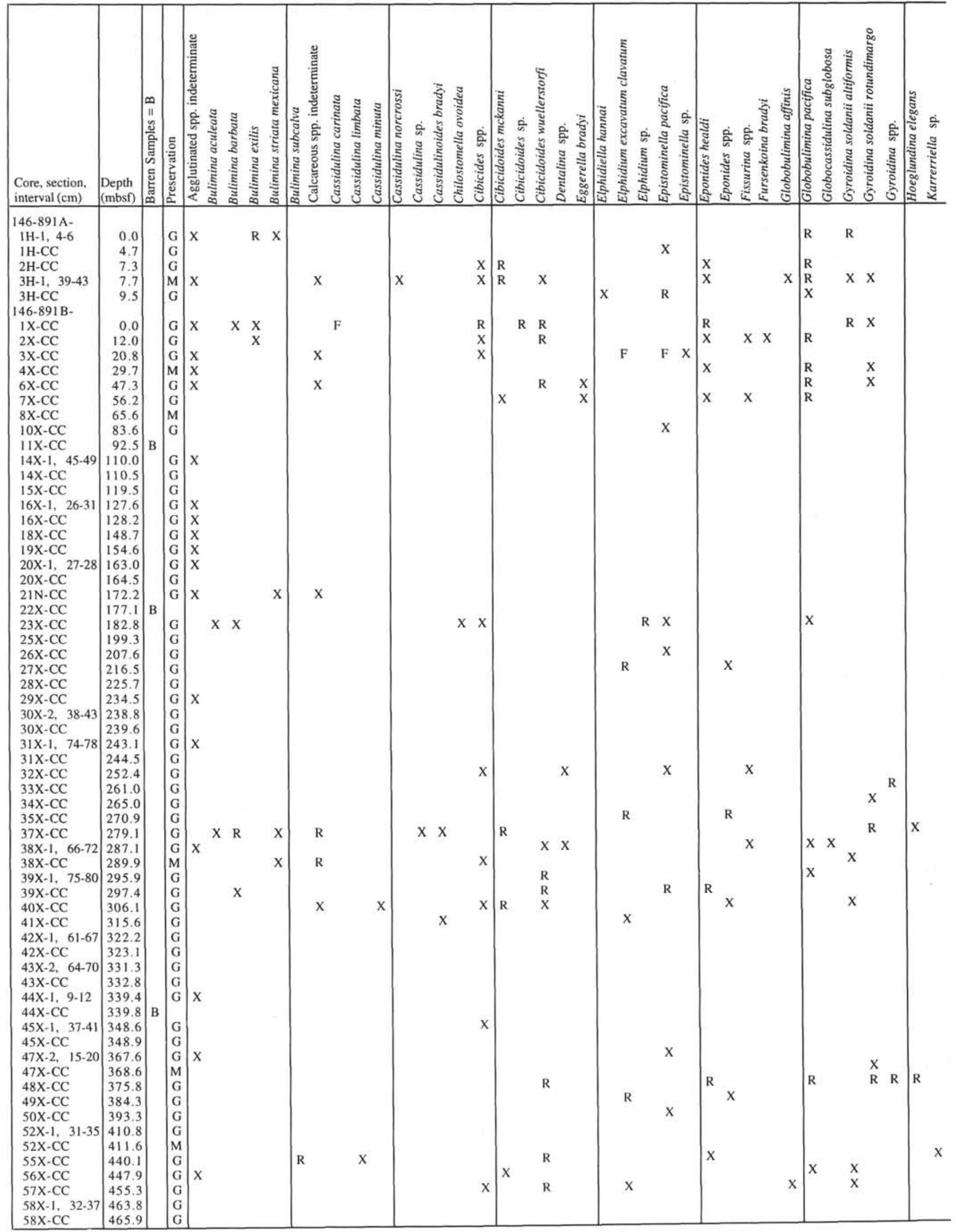

Note: $\mathrm{B}=$ barren samples; see text for explanation of additional abbreviations. 
Table 4 (continued).

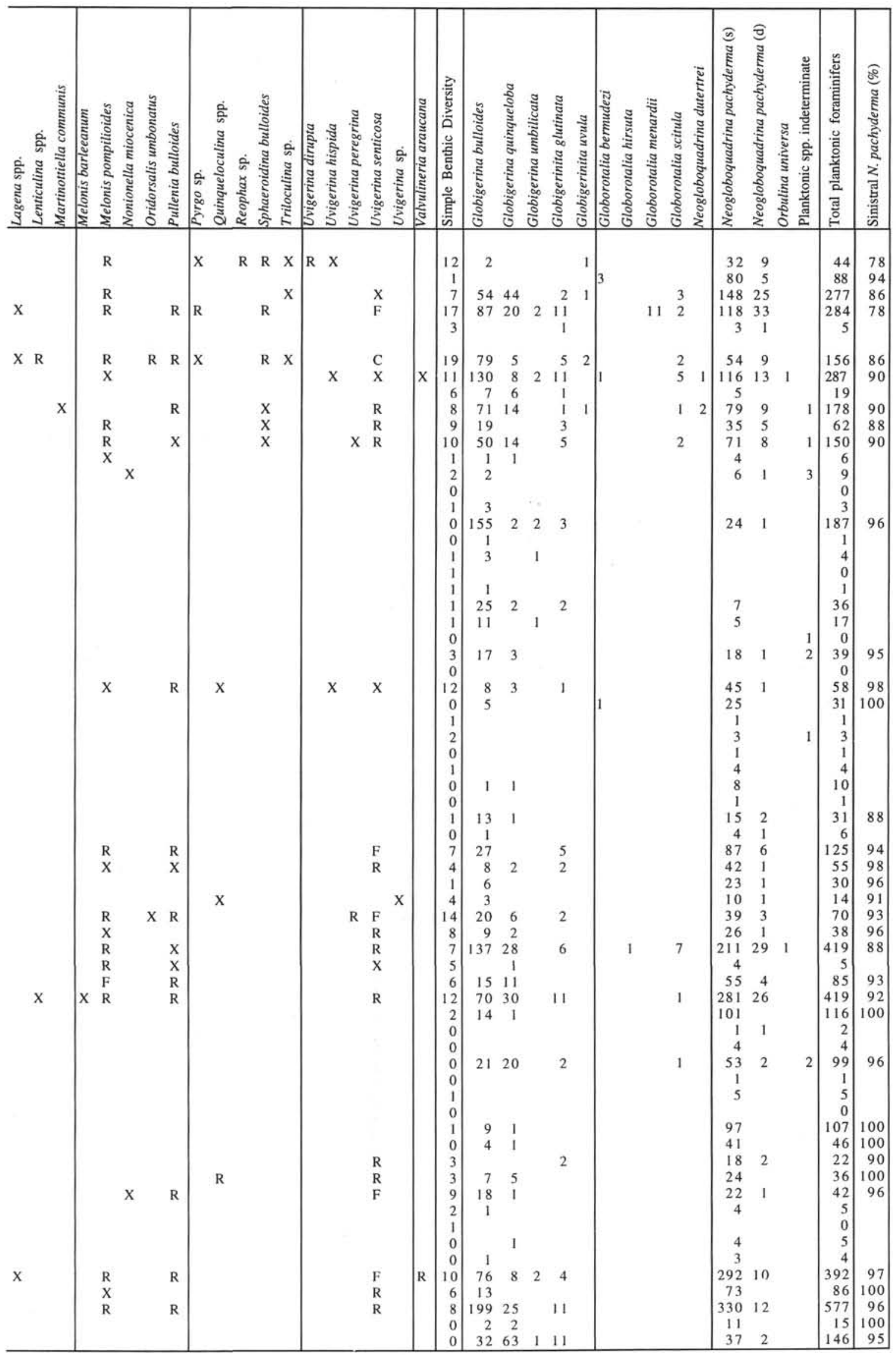


dergone between 200 and $700 \mathrm{~m}$ of uplift. Site 889 is presently in an upper middle bathyal environment, so sediments in Subunit IA, which are indicative of a middle bathyal environment, have not been uplifted more than $200 \mathrm{~m}$.

\section{Planktonic Foraminifers \\ Holes $890 \mathrm{~A}$ and $890 \mathrm{~B}$}

The five core-catcher samples from Holes $890 \mathrm{~A}$ and $890 \mathrm{~B}$ contain well preserved, very abundant faunas dominated by $G$. bulloides, $N$. pachyderma (sinistral), and G. quinqueloba. There are also rare to few occurrences of G. scitula, G. bermudezi, G. umbilicata, and N. pachyderma (dextral). Radiolarians indicative of the B. aquilonaris Zone are present in Sample 146-890A-1H-CC, but are rare or absent in other samples at Site 890 . The sequence at Site 890 is considered to be late Pleistocene.

\section{Benthic Foraminifers}

Core-catcher samples from Holes 890A and 890B contain assemblages dominated by Bolivina spissa, B. striata mexicana, Bulimina subcalva, B. exilis, B. subacuminata, Globobulimina pacifica, Epistominella pacifica, Chilostomella oolina, Cassidulinoides bradyi, Cibicidoides mckannai, Oridorsalis umbonatus, Uvigerina peregrina, Cassidulina translucens. Pyrgo spp., Quinqueloculina spp., Elphidium excavatum clavatum, $C$. minuta, $C$. norcrossi and other neritic taxa are also present. An upper middle bathyal environment with a large component of transported neritic through upper bathyal faunas is indicated for Site 890.

\section{OREGON MARGIN: SITES 891 AND 892}

\section{Site 891}

Site $891\left(44^{\circ} 38.64{ }^{\prime} \mathrm{N}, 125^{\circ} 19.550 \mathrm{~W}\right.$, water depth $\left.=2663 \mathrm{~m}\right)$ is located on the westernmost ridge of the accretionary wedge along the Oregon continental margin (Fig. 1). Total penetration at this site was $472.3 \mathrm{~m}$, however recovery was very poor $(11 \%)$.

Due to the poor recovery and compositional and textural similarity of all the sediments recovered at Site 891 , only one lithostratigraphic unit was recognized. The lithologies at this site are mainly clayey silts and fine- to medium-grained sands, with pebbles and diagenetic carbonate concretions scattered throughout the section. Steeply inclined beds that dip about $60^{\circ}$ above $84 \mathrm{mbsf}$ overlie variably dipping beds to 198 mbsf. From 198 to 375 mbsf fractures and two fault zones are recognized in the sequence (Shipboard Scientific Party, 1994d). These sediments probably represent deep-sea fan deposits that were later accreted to the lower slope of the Oregon Margin.

\section{Planktonic Foraminifers}

Moderately to well-preserved planktonic foraminifers are rare to abundant in samples from Holes 891A and 891B (Table 4). Five out of 66 samples are barren of planktonic foraminifers.

The abundance of planktonic foraminifers varies greatly throughout the hole (Fig. 6); three intervals, based on abundance, can be recognized at this site. From 0 to $56.2 \mathrm{mbsf}$, planktonic foraminifers are abundant in most samples. The assemblages are dominated by $N$. pachyderma (sinistral and dextral), G. bulloides, G. quinqueloba, $G$. glutinata, and G. scitula. This interval is dominated by sinistral $N$. pachyderma, with the exception of the first sample (146-891 A-1H-1, 4-6 cm). The interval from 56.2 to 244.5 mbsf contains lower abundances of planktonic foraminifers, with the exception of Sample 146891B-14X-CC. This interval contains common N. pachyderma (sinistral) and $G$. bulloides with scattered rare occurrences of $N$. pachy- derma (dextral), G. quinqueloba, and G. glutinata. G. scitula is absent in this interval. The last interval, from 244.5 to $465.9 \mathrm{mbsf}$, consists of similar faunas present in the first interval described. This interval is dominated by sinistrally coiled assemblages of $N$. pachyderma.

The age of the sediments recovered at Site 891 is considered to be late Quaternary, possibly in the CD1-8 zones, based on the occurrence of coeval radiolarians, a normal paleomagnetic signature (Shipboard Scientific Party, 1994d), and the dominance of sinistrally coiled $N$. pachyderma. A more precise age is not possible due to the following factors: (1) poor recovery; (2) absence of zonal markers; (3) structural deformation; and (4) intervals barren of siliceous microfossils.

\section{Benthic Foraminifers}

The distribution of benthic foraminifers at Site 891 is similar to that at Site 888; samples from Site 891 are either barren, contain very rare, low to moderate diversity foraminifers, or contain common, moderate diversity assemblages (Fig. 6). Abundances of benthic foraminifers are generally lower at this site, with most taxa being very rare to few in abundance; no benthic species is abundant at this site (Table 4).

Abundance, diversity, and composition of the faunas can be generalized in six intervals. The intervals from 0 to $56.2,252.4$ to 315.6 , and 375.8 to 455.3 mbsf contain common, moderate diversity assemblages dominated by Uvigerina senticosa, Melonis pompilioides, Pullenia bulloides, and Cibicidoides wuellerstorfi. Samples in the intervals from 65.6 to $244.5,322.2$ to 368.8 , and 455.3 to $465.9 \mathrm{mbsf}$ are either barren or contain very few benthic foraminifers. Many of these samples contain only broken specimens of unilocular agglutinated benthic foraminifers. Deposition in a lower bathyal environment is suggested by the benthic faunas.

\section{Site 892}

A discontinuous, structurally complex sequence of sediments was cored at Site 892 , located on the continental slope $\left(44^{\circ} 40.451 \mathrm{~N}\right.$, $125^{\circ} 7.139$ W) in a water depth of $674 \mathrm{mbsl}$ (Fig. 1). The site crosses a thrust fault and related faults associated with accretionary processes on the second ridge of the accretionary wedge off Oregon (Shipboard Scientific Party, 1994e). Sediments at Site 892 are mainly terrigenous silty clays and clayey silts with sporadic sand layers, interpreted to be abyssal plain deposits.

Diatom and radiolarian biostratigraphic studies (Fourtanier and Caulet, this volume) show a complicated stratigraphy with fault-juxtaposed sediments of Pleistocene, Pliocene, and Miocene age. The distribution of age-diagnostic foraminifers shows general agreement with ages determined by siliceous microfossils.

\section{Planktonic Foraminifers}

Planktonic foraminifers are either common to abundant or absent to rare in samples from both Holes $892 \mathrm{~A}$ (Table 5, Fig. 7) and 892D (Table 6, Fig. 8). Where common to abundant, planktonic assemblages are dominated by $N$. pachyderma (dextral), $G$. bulloides, $N$. asanoi, and $N$. pachyderma (sinistral). Coiling directions are mainly to the right or are mixed, indicating cool temperate surface waters (Figs. 7 and 8). Samples in a thick interval in Hole 892D from 39.14 to $119 \mathrm{mbsf}$ are either barren or contain very rare planktonic foraminifers. One sample in this interval, 146-892D-10X-6, 6-67 cm, contains rare specimens of Catapsydrax $\mathrm{sp}$. and Morozovella aragonensis and Eocene benthic foraminifers (see below).

Direct age assignments of samples to the $N$. pachyderma coiling zones can not be made at Site 892 because the sediments are deformed. However, the coiling zone to which each sample probably belongs can be inferred (Figs. 7 and 8 ) based on the age determina- 


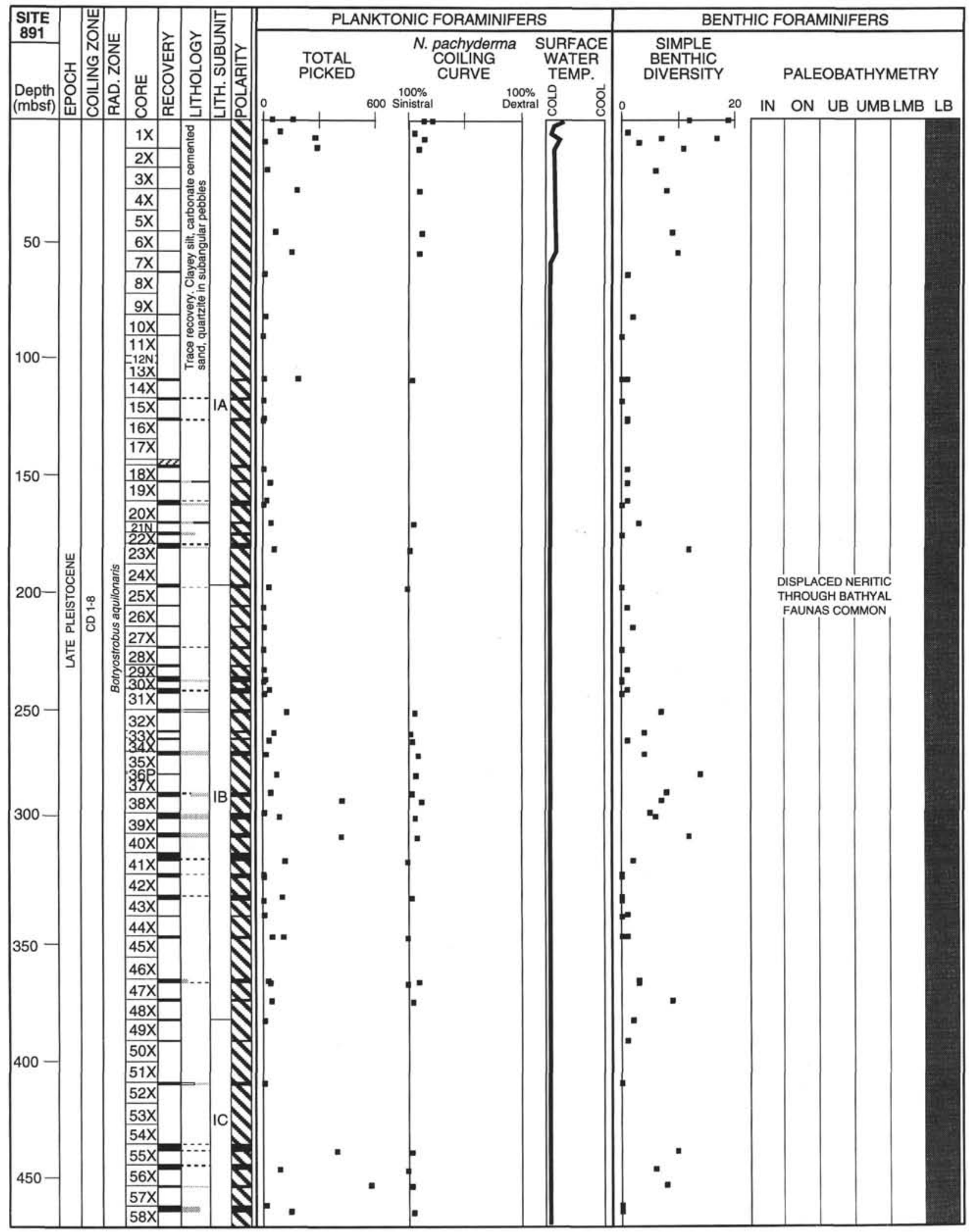

Figure 6. Summary of age zonation, core recovery, lithology, magnetic polarity, foraminiferal distributions, inferred sea-surface temperatures, and paleobathymetry at Site 891 . Key to lithologic symbols: fine stipple $=$ mud; coarse stipple $=$ sand; thin dashed pattern $=$ silt. Key to polarity units: black $=$ normal polarity and diagonal $=$ undetermined. Thrust faults are located at $260 \mathrm{mbsf}$ and $275 \mathrm{mbsf}$. See Shipboard Scientific Party (1994d) for radiolarian zonations and more detailed lithologic, paleomagnetic information, and structural information. 
tions provided by radiolarian (Caulet, this volume) and diatom (Fourtanier, this volume) biostratigraphy.

\section{Benthic Foraminifers}

Benthic foraminiferal faunas are similar in Holes 892A and 892D (Tables 5 and 6). Most species are rare to common, with only a few abundant occurrences. A Q-mode cluster analysis was done in order to characterize the benthic faunas in these holes. Thirty taxa in 35 samples from Holes 892A and 892D were analyzed using the Cosine Theta similarity coefficient and UWPGMA. Five cluster groups can be recognized in the resulting dendrogram (Fig. 9A). As discussed above, each group can be characterized using a preference index (PI) for each species analyzed (Fig. 9B). In general the five cluster groups have both paleoenvironmental and chronostratigraphic significance (Figs. 7, 8, and 10). In the following discussion, age references are based on diatom biostratigraphy of Fourtanier (this volume).

Cluster group I consists of 12 samples from both holes that have high PIs for Uvigerina senticosa, Melonis pompilioides, Globobulimina pacifica, U. peregrina, various buliminids, Pullenia bulloides, Nodosaria spp., and Cibicidoides wuellerstorfi (Fig. 9A and B). These taxa indicate a lower bathyal environment with downslope transport of faunas from an upper bathyal environment. The ages of samples in this group are Pliocene except for Samples 146-892D-1XCC and 892D-2X-CC, which are Pleistocene (Figs. 7, 8, and 10).

Cluster group II consists of 10 samples with high PIs for Bulimina subacuminata, $M$. barleeanum, costate Nodosaria spp., Cassidulina norcrossi, Stilostomella sp., Plectofrondicularia sp., Epistominella pacifica, and other taxa shown in Figure 9B. This assemblage suggests deposition in a lower bathyal environment with a large component transport of outer neritic through middle bathyal faunas. The ages of samples in this group are Pliocene except for Sample 146892D-2X-1, 1-6 cm, which is Pleistocene (Figs. 7, 8, and 10).

Only two samples occur in cluster group III. These samples are distinguished on the basis of common Gyroidina soldanii altiformis and C. translucens, and rare B. subcalva in Sample 146-892A-7X-2, $10-15 \mathrm{~cm}$ (Fig. 9B). Sample 146-892D-9X-CC clusters with the other sample because of the occurrence of B. subcalva and rare $G$. soldanii altiformis. These two samples are both early Pliocene in age and represent deposition in a bathyal environment (Figs. 7, 8, and 10).

The six samples that make up cluster group IV can be characterized by the following taxa: Buliminella subfusiformis, Nonionellina labradorica, Bolivina spissa, Buccella tenerrima, U. hootsi, Globocassidulina subglobosa, E. pacifica, P. bulloides, Martinottiella communis, and C. wuellerstorfi (Fig. 9B). This assemblage is indicative of a lower bathyal environment with a significant component of transported inner neritic faunas (e.g., B. tenerrima). All samples in this group are considered to be Miocene in age (Figs. 7, 8, and 10).

The final cluster group, VI, groups four samples characterized by the occurrence of Silicosigmoilina sp. and $M$. communis. Two of the samples in this group are Miocene (Samples 146-892A-8X-CC and 892D-6X-CC) and two are Pliocene in age (Samples 146-892D-7XCC and 892D-4X-1, 99-105 cm). These taxa represent a lower bathyal environment that is distinctly different, and possibly deeper, than the environments suggested by cluster groups I, II and IV.

One sample was not included in the cluster analysis because it contains a much different assemblage than any other sample at this site (Table 6). Sample 146-892D-10X-6, 63-67 cm, is composed of the following benthic foraminifers indicative of an Eocene age: Tritaxilina colei, Buccella oregonensis, Bulimina jacksonensis welcomensis, Bulimina microcostata, Cibicides perlucida, Cassidulina globosa, Eponides minima, Gyroidina orbicularis planata, Lenticulina texana, and Uvigerina garzaensis. Also present in this sample are Plectofrondicularia californica, N. pachyderma (dextral and sinistral), N. asanoi, G. bulloides, indicating the presence of Pliocene faunas as well. The washed residue for this sample has a salt and pepper appearance with mainly very dark, almost black, silty clays mixed with a smaller component of very light-colored silty clays. Most of the other washed residues at this site resemble the lighter component. This sample is in the "most intensely deformed zone recovered" (Shipboard Scientific Party, 1994e, p. 330) at Site 892 and it is suggested that Eocene material occurs in a fault sliver or was brought up within this fault zone and mixed with Pliocene material. Another possibility is that the fauna in Sample 146-892D-10X-6, $63-67 \mathrm{~cm}$ represent a land-derived turbidite.

Most of the sediments at Site 892 were deposited in a lower bathyal environment. The present water depth at Site 892 is at $674 \mathrm{mbsl}$ in an upper middle bathyal environment. Therefore, the sediments at Site 892 have undergone a net uplift of 1300 to $3300 \mathrm{~m}$.

\section{SUMMARY}

A 600-m sequence of upper Quaternary sediments, representing turbidites deposited in a lower bathyal environment on outer to middle portions of the Nitinat submarine fan, was recovered at Site 888 . Assemblages of $N$. pachyderma show a change from dominantly cold surface waters to those that fluctuate between cold to slightly warmer at Site 888. These changes reflect regional paleoclimatic fluctuations and may also indicate changes in the nature of surface currents along the margin. Benthic foraminiferal faunas are rare to abundant, with a large component of displaced faunas from both neritic and bathyal environments deposited in a lower bathyal environment. The occurrence of neritic taxa and wood fragments suggests a shelf origin for some of these turbidites.

A discontinuous sequence of upper Pliocene through Quaternary sediments was cored at Site 889 , and an apparently continuous upper Quaternary sequence was cored at Site 890 . Surface waters were dominantly cool temperate during the late Pliocene to early Pleistocene at Site 889 , with cold surface waters in the late Pleistocene. Benthic foraminifers suggest a decrease in paleobathymetry through time from lower bathyal to upper middle bathyal environments as sediments at Site 889 were uplifted and accreted to the Cascadia accretionary wedge.

Site 891 contains Quaternary turbidites deposited in a lower bathyal environment beneath dominantly cold surface waters.

A structurally complex sequence, containing abyssal plain sediments indicative of a variety of ages ranging from Pleistocene to Miocene, and possibly Eocene, was recovered at Site 892. Cluster analysis was successful in classifying samples from Site 892 on the basis of age and paleobathymetry. Most of the samples contain faunas indicative of deposition in a lower bathyal environment.

\section{ACKNOWLEDGMENTS}

The assistance of the scientists, marine specialists, and crew on board the JOIDES Resolution is greatly appreciated. I am particularly grateful to Jean-Pierre Caulet and Bob Musgrave for their help during the cruise. I would like to thank Kristin McDougall, Peter Thompson, and Martin Lagoe for their valuable reviews of this manuscript. I also thank the University of California, Berkeley and the Smithsonian Institution for access to their foraminiferal collections. Financial support for this research was from grant USSSP \#146-20701b.

\section{REFERENCES}

Bailey, J.W., 1851. Microscopical examination of soundings made by the United States Coast Survey, off the Atlantic Coast of the United States. Smithson. Contrib. Knowl., 2:1-15.

Bandy, O.L., 1950. Some later Cenozoic foraminifera from Cape Blanco, Oregon. J. Paleont., 24:269-281.

Barker, R.W., 1960. Taxonomic notes on the species figured by H. B. Brady in his report on the Foraminifera dredged by H.M.S. Challenger during 
the years 1873-1876. Spec. Publ. Soc. Econ. Paleontol. Mineral., 9:1238.

Beck, R.S., 1943. Eocene foraminifera from Cowlitz River, Lewis County, Washington. J. Paleont., 17:584-614.

Blow, W.H., 1969. Late middle Eocene to Recent planktonic foraminiferal biostratigraphy. In Brönniman, P., and Renz, H.H. (Eds.), Proc. First Int. Conf. Planktonic Microfossils, Geneva, 1967: Leiden (E.J. Brill), 1:199422.

Brady, H.B., 1881. Notes on some of the reticularean Rhizopoda of the Challenger Expedition, Part III. 1. Classification. 2. Further notes on new species. 3. Note on Biloculina mud. Q. J. Microsc, Sci., 19:20-63.

1882. Report on the Foraminifera. In Tizard and Murray, J. (Eds.), Exploration of the Faröe Channel During the Summer of 1880, in Her Majesty's Ship Knight Errant, with Subsidiary Reports. Proc. R. Soc. Edinburgh, 11:708-717.

, 1884. Report on the Foraminifera dredged by H.M.S. Challenger, during the years 1873-1876. Rep. Sci. Results Challenger Exped., Zool., 9:1-814

Cande, S.C., and Kent, D.V., 1992. A new geomagnetic polarity time scale for the Late Cretaceous and Cenozoic. J. Geophys. Res., 97:1391713951.

Cushman, J.A., 1911. A monograph of Foraminifera of the North Pacific Ocean, Part 2. Textulariidae. Bull. U.S. Nat. Mus., 71:1-108.

, 1913. New Textulariidae and other arenaceous foraminifera from the Philippine Islands and contiguous waters. Proc. U.S. Nat. Mus., 44:633-638.

1922a. The Foraminifera of the Atlantic Ocean, Part 3. Textulariidae. Bull. U.S. Nat. Mus., 104:1-149.

1922b. Results of the Hudson Bay Expedition 1920, I. The Foraminifera. Contrib. Can. Biol., 9:135-147.

1923. The Foraminifera of the Atlantic Ocean, Part 4. Lagenidae. Bull. U.S. Nat. Mus., 104:1-228.

1925a. Recent foraminifera from British Columbia. Contrib. Cushman Lab. Foraminiferal Res., 1:38-47.

1925b. Some Textulariidae from the Miocene of California. Contibr. Cushman Lab. Foraminiferal Res., 1:29-35.

, 1926a. Foraminifera of the typical Monterey of California. Contrib. Cushman Lab. Foraminiferal Res., 2:53-66.

, 1926b. Some Pliocene Bolivinas from California. Contrib. Cush man Lab. Foraminiferal Res., 2:40-47.

, 1927a. An outline of a reclassification of the foraminifera. Contrib. Cushman Lab. Foraminiferal Res., 3:1-105.

1927b. Recent foraminifera from off the west coast of America Scripps Inst. Oceanogr. Tech. Ser., 1:119-188.

, 1930. The foraminifera of the Atlantic Ocean, Part VII. Nonionidae, Camerinidae, Peneroplidae and Alveolinellidae. Bull U.S. Nat. Mus., 104:1-79.

, 1933a. New Arctic foraminifera collected by Captain R.A. Bartlett from Fox Basin and off the northeast coast of Greenland. Smithson. Misc. Collect. (pub. 3221), 89:1-8.

1933b. New foraminifera from the upper Jackson Eocene of the southeast coastal plain region of the United States. Contrib. Cushman Lab. Foraminiferal Res., 9:1-21.

1933c. Some new Recent foraminifera from the tropical Pacific Contrib. Cushman Lab. Foraminiferal Res., 9:77-95.

1935. Upper Eocene foraminifera of the southeastern United States. Geol. Surv. Prof. Pap. U.S., 181:1-88.

Cushman, J.A., and Applin, E.R., 1926. Texas Jackson Foraminifera. AAPG Bull., 10:154-189.

Cushman, J.A., and Grant, U.S., IV, 1927. Late Tertiary and Quaternary Elphidiums of the West Coast of North America. Trans. San Diego Soc. Nat. Hist., 5:69-82.

Cushman, J.A., and Hughes, D.D., 1925. Some later Tertiary Cassidulinas of California. Contrib. Cushman Lab. Foraminiferal Res., 1:11-17.

Cushman, J.A., and Kleinpell, R.M., 1934. New and unrecorded foraminifera from the California Miocene. Contr. Cushman Lab. Foraminiferal Res. 10:1-23.

Cushman, J.A., and Parker, F.L., 1936. Some American Eocene buliminas. Contrib. Cushman Lab. Foraminiferal Res., 12:39-45.

1938. Notes on some Pliocene and Pleistocene species of Bulim ina and Buliminella. Contr. Cushman Lab. Foram. Res., 14:53-62.

, 1940. The species of the genus Bulimina having Recent types. Contrib. Cushman Lab. Foraminiferal Res., 16:7-23.

Cushman, J.A., and Siegfus, S.S., 1935. New Species of Foraminifera from the Kreyenhagen Shales of California. Contrib. Cushman Lab. Foraminiferal Res., 11:90-95.
1939. Some new and interesting foraminifera from the Kreyenhagen Shales of California. Contrib. Cushman Lab. Foraminiferal Res., 15:23-33.

Cushman, J.A., and Stewart, R.E., 1926. A new Plectofrondicularia from the Pliocene of California. Contrib. Cushman Lab. Foraminiferal Res., 2:39.

Cushman, J.A., Stewart, R.E., and Stewart, K.C., 1930. Tertiary foraminifera from Humboldt County California. A preliminary survey of the fauna. Trans. San Diego Soc. Nat. Hist., 6:41-94.

, 1947. Astoria Miocene foraminifera from Agate Beach, Lincoln County, Oregon. Bull. Oreg. Dep. Geol. Miner. Ind., 36:41-51.

Cushman, J.A., and Todd, R., 1941. Notes on the species of Uvigerina and Angulogerina described from the Pliocene and Pleistocene. Contrib. Cushman Lab. Foraminiferal Res., 17:70-78.

Dawson, J.W., 1860. Notice of Tertiary fossils from Labrador, Maine, etc. and remarks on the climate of Canada in the newer Pliocene or Pleistocene period. Can. Nat., 5:188-200.

Deshayes, G.P., 1832. Encyclopédia méthodique. Hist. Nat. des Vers., 2:1594.

d'Orbigny, A.D., 1826. Tableau méthodique de la classe des céphalopodes. Ann. Sci. Nat., Paris, Ser. 1, 7:96-314.

, 1839a. Foraminiferes. In de la Sagra, R. (Ed.), Histoire Physique, Politique et Naturelle de L'île de Cuba: Paris (Arthus Bertrand), 8:1-224 [plates published separately].

, 1839b. Foraminiferes des iles Canaries. In Barker-Webb, P., and Berthelot, S. (Eds.), Histoire Naturelle des Iles Canaries (Vol. 2, Pt. 2): Paris (Béthune), 119-146.

1839c. Voyage dans l'Amerique Meridionale foraminiferes. Ann. Sci. Nat., Ser. 5, 5:1-86.

, 1846. Foraminifères Fossiles du Bassin Tertiaire de Vienne (Autriche): Paris (Gide et Comp.)

Egger, J.C., 1893. Foraminiferen aus Meeresgrundproben, gelothet von 1874 bis 1876 von S.M. Sch. Gazelle. Abh. Bayer. Akad. Wiss., Math.-Physik. Kl., 18:193-458.

Ehrenberg, C.G., 1861. Elemente des tiefen Meeresgrundes im Mexikanischen Golfstrome bei Florida; über die Tiefgrund-Verhältnisse des Oceans am Eingange der Davisstrasse und bei Island. K. Preuss. Akad. Wiss. Berlin, Monatsbericht, 1861:275-315.

Fichtel, L., von, and Moll, J.P.C., 1798. Testacea Microscopica, Aliaque Minuta Ex Generibus Argonauta et Nautilus, Ad Naturam Picta Descripta: Vienna (Camesina)

Finger, K.L., 1990. Atlas of California Neogene foraminifera. Spec. Publ. Cushman Found. Foraminiferal Res., 281-271.

Galloway, J.J., and Wissler, S.G., 1927. Pleistocene foraminifera from the Lomita Quarry, Palos Verdes Hills, California. J. Paleontol., 1:35-87.

Haller, C.R., 1980. Pliocene Biostratigraphy of California. AAPG Stud. Geol., 11:183-341.

Hays, J.D., 1970. Stratigraphy and evolutionary trends of radiolaria in North Pacific deep sea sediments. In Hays, J.D. (Ed.), Geological Investigations of the North Pacific. Mem. Geol. Soc. Am., 126:185-218.

Heron-Allen, E., and Earland, A., 1913. Clare Island Survey, Part 64. Foraminifera. Proc. R. Ir. Acad. 31:1-188.

Ingle, J.C., Jr., 1973. Neogene foraminifera from the northeastern Pacific Ocean, Leg 18, Deep Sea Drilling Project. In Kulm, L.D., von Huene, R., et al., Init. Repts. DSDP, 18: Washington (U.S. Govt. Printing Office), 517-567.

, 1980. Cenozoic paleobathymetry and depositional history of selected sequences within the southern California continental borderland. Spec. Publ. Cushman Found. Foraminiferal Res., 19:163-195.

Ishiwada, Y., 1950. Foraminiferal death assemblages from the mouth of Toyama Bay. Bull. Geol. Surv. Japan, 1:182-195. (in Japanese)

Keller, G., 1980. Planktonic foraminiferal biostratigraphy and paleoceanography of the Japan trench, Leg 57, Deep Sea Drilling Project. In Scientific Party, Init. Repts. DSDP, 56, 57 (Pt. 2): Washington (U.S. Govt. Printing Office), 809-833.

Kennett, J.P., 1982. Marine Geology: Englewood Cliffs, NJ (Prentice-Hall).

Kennett, J.P., and Srinivasan, M.S., 1983. Neogene Planktonic Foraminifera: A Phylogenetic Atlas: Stroudsburg, PA (Hutchinson Ross).

Lagoe, M.B., and Thompson, P.R., 1988. Chronostratigraphic significance of late Cenozoic planktonic foraminifera from the Ventura Basin, California: potential for improving tectonic and depositional interpretation. $J$. Foraminiferal Res., 18:250-266.

Maiya, S., Saito, T., and Sato, T., 1976. Late Cenozoic planktonic foraminiferal biostratigraphy of Northwest Pacific sedimentary sequences. In Takayanagi,Y., and Saito, T. (Eds.), Progress in Micropaleontology: Selected Papers in Honor of Prof. Kiyoshi Asano: New York (Micropaleontology Press), 395-422. 
Mallory, V.S., 1959. Lower Tertiary Biostratigraphy of the California Coast Ranges: Tulsa, OK (AAPG).

Natland, M.L., 1938. New species of Foraminifera from off the West Coast of North America and from the later Tertiary of the Los Angeles basin. Scripps Inst. Oceanogr. Bull. Tech. Ser., 4:137-164.

Nörvang, A., 1945. The Zoology of Iceland (Vol. 2, Pt. 2): Copenhagen (Ejnar Munsgaard), 1-79.

Nuttall, W.L.F., 1930. Eocene Foraminifera from Mexico. J. Paleontol., 4:271-293. $6: 3-35$

Orr, W.N., and Zaitzeff, J.B., 1971. A new planktonic foraminiferal species from the California Pliocene. J. Foraminiferal Res., 1:17-19.

Parker, W.K., and Jones, T.R., 1865. On some foraminifera from the North Atlantic and Arctic Oceans, including Davis Straits and Baffin's Bay. Philos. Trans. R. Soc. London, 155:325-441.

Parker, W.K., Jones, T.R., and Brady, H.B., 1865. On the nomenclature of the foraminifera, Part XII. The species enumerated by d'Orbigny in the Annales des Sciences Naturelles, vol. 7, 1826. Ann. Mag. Nat. Hist., Ser. $3,16: 15-41$.

Phleger, F.B., 1951. Gulf of Mexico Foraminifera, Part I. Foraminifera Distribution. Mem. Geol. Soc. Am., 46:1-88.

Reuss, A.E., 1850. Neue Foraminiferen aus den Schichten des Oesterreichischen Tertiärbeckens. Sitzaber. K. Akad. Wiss., Wien, Math.-Naturw., Kl., Denkschrift, 1:365-390.

, 1851. Uber die fossilen Foraminiferen und Entomostracean der Septarienthone der umgegend von Berlin. Z Dtsch. Geol. Ges., 3:49-92.

Rögl, F., and Bolli, H.M., 1973. Holocene to Pleistocene planktonic foraminifera of Leg 15, Site 147 (Cariaco Basin [Trench], Caribbean Sea) and their climatic interpretation. In Edgar, N.T., Saunders, J.B., et al., Init. Repts. DSDP, 15: Washington (U.S. Govt. Printing Office), 553-615.

Saito, T., Thompson, P.R., and Breger, D., 1981. Systematic Index of Recent and Pleistocene Planktonic Foraminifera: Tokyo (Univ. of Tokyo).

Schwager, C., 1866. Fossile Foraminiferen von Kar Nikobar. Novara Expedition, 1857 1859, Wein, Geol. Theil, 2:187-268.
Shipboard Scientific Party, 1994a. Explanatory notes. In Westbrook, G.K., Carson, B., Musgrave, R.J., et al., Proc. ODP, Init. Repts., 146 (Pt. 1): College Station, TX (Ocean Drilling Program), 15-48.

, 1994b. Site 888. In Westbrook, G.K., Carson, B., Musgrave, R.J., et al., Proc. ODP, Init. Repts., 146 (Pt. 1): College Station, TX (Ocean Drilling Program), 55-125.

, 1994c. Sites 889 and 890. In Westbrook, G.K., Carson, B., Musgrave, R.J., et al., Proc. ODP, Init. Repts., 146 (Pt. 1): College Station, TX (Ocean Drilling Program), 127-239.

1994d. Site 891. In Westbrook, G.K., Carson, B., Musgrave, R.J., et al., Proc. ODP, Init. Repts., 146 (Pt. 1): College Station, TX (Ocean Drilling Program), 241-300.

, 1994e. Site 892. In Westbrook, G.K., Carson, B., Musgrave, R.J., et al., Proc. ODP, Init. Repts., 146 (Pt. 1): College Station, TX (Ocean Drilling Program), 301-378.

Stewart, R.E., and Stewart, K.C., 1930. Post-Miocene foraminifera from the Ventura Quadrangle, Ventura County, California. J. Paleontol., 4:127239.

Takayanagi, Y., 1953. New genus and species of foraminifera found in the Tonohama group, Kochi Prefecture, Shikoku, Japan. Tohoku Univ. Inst. Geol. Paleontol. Short Pap., 5:25-36.

Takayanagi, Y., and Saito, T., 1962. Planktonic foraminifera from the Nobori Formation, Shikoku, Japan. Sci. Rep. Tohoku Univ., Ser. 2, 5:647-106.

Tappan, H., 1951. Northern Alaska index foraminifera. Contrib. Cushman Lab. Foraminiferal Res., 2:1-8.

Todd, R., 1948. Subfamily Uvigerininae. In Cushman, J.A., and McColloch, I. (Eds.), The Species of Bulimina and Related Genera in the Collections of the Allan Hancock Foundation: Los Angeles (Southern Calif. Univ. Publ., Allen Hancock Pacific Expedition), 6:231-294.

1965. The foraminifera of the tropical Pacific collections of the Albatross, 1899 1900, Part 5. Rotaliform families and planktonic families, Bull. U.S. Nat. Mus., 161:1-139.

Westbrook, G.K., Carson, B., Musgrave, R.J., et al., 1994. Proc. ODP, Init. Repts., 146 (Pt. 1): College Station, TX (Ocean Drilling Program).

Table 5. Checklist of foraminifers found at Hole 892A.

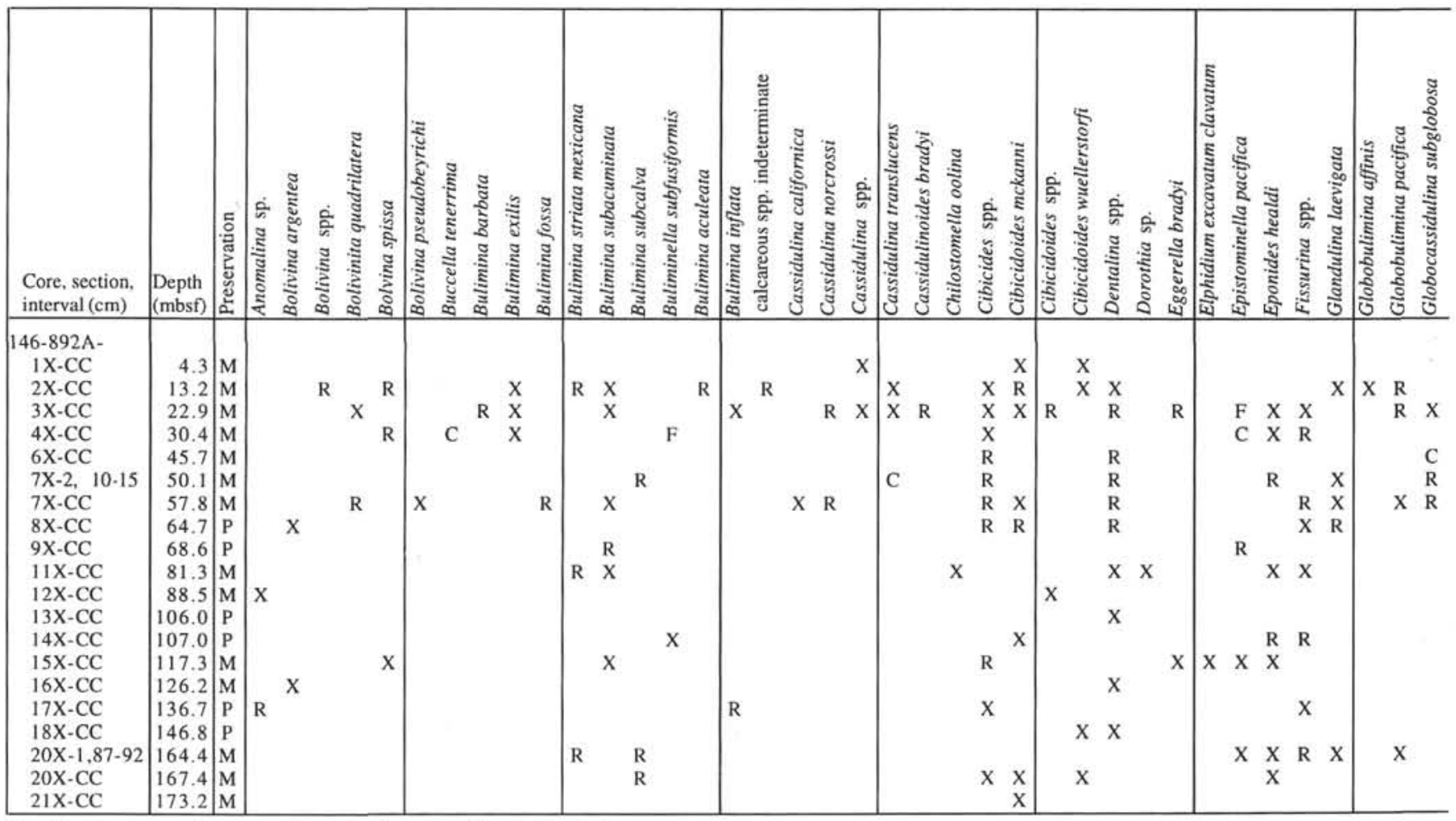

Note: $\mathrm{B}=$ barren samples; see text for explanation of additional abbreviations. 
Williamson, W.C., 1858. On the Recent Foraminifera of Great Britain: London (Ray Society).

Date of initial receipt: 25 August 1994

Date of acceptance: 3 February 1995

Ms 146SR-208

\section{APPENDIX}

\section{Taxonomic Notes}

Original references for species listed in the tables are given below. Individual specimens that could only be identified to genus level are listed on Tables 1 to 6 as "sp." Multiple specimens of the same genus, not identified to species level, are designated as "spp."

Catapsydrax sp. Only one broken specimen found.

Globigerina bulloides d'Orbigny, 1826, p. 277

Globigerina quinqueloba Natland, 1938, p. 149, pl. 6, fig. 7.

Globigerina umbilicata Orr and Zaitzeff, 1971, p. 18, 19, pl. 1, figs. 1-3.

Globigerinita glutinata $($ Egger $)=$ Globigerina glutinata Egger, 1893, p. 371, pl. 13, figs. 19-21.

Globigerinita uvula $($ Ehrenberg $)=$ Pylodexia uvula Ehrenberg, 1861, p. 206, 207, 308.

Globigerinoides ruber (d'Orbigny) = Globigerina rubra d'Orbigny, 1839a, p. 82 , pl. 4, figs. $12-14$.

Globorotalia bermudezi Rögl and Bolli, 1973, p. 567, pl. 6, figs. 16 20, pl. 16 , figs. 13 , text figs. $6 a-6 c$.

Globorotalia crassiformis (Galloway and Wissler) $=$ Globigerina crassiformis Galloway and Wissler, 1927, v. 1, p. 41, pl. 7, fig. 12.

Globorotalia hirsuta (d'Orbigny) $=$ Rotalina hirsuta d'Orbigny, 1839b, p. 131, pl. 1, figs. 37-39.
Globorotalia inflata $\left(\mathrm{d}^{\prime}\right.$ Orbigny $)=$ Globigerina inflata d'Orbigny, $1839 \mathrm{~b}, \mathrm{p}$. 134 , pl. 2, figs $7-9$.

Globorotalia inflata primitive var. $=$ earliest forms of Globorotalia inflata as described by Keller (1980).

Globorotalia menardii $($ Parker, Jones, and Brady $)=$ Rotalia menardii Parker et al., 1865, p. 20, pl. 3, fig. 81.

Globorotalia praeinflata $=$ Globorotalia inflata $(\mathrm{d}$ 'Orbigny) praeinflata Maiya et al., 1976, p. 408, pl. 2, figs. 5-7.

Globorotalia puncticulata $($ Deshayes) $=$ Globigerina puncticulata Deshayes, 1832 , v. 2 , no. 2 , p. 170

Globorotalia scitula $($ Brady $)=$ Pulvinulina scitula Brady, 1882, p. 716 .

Morozovella aragonensis = Globorotalia aragonensis Nuttall, 1930, v. 4, no. 3 , p. 288 , pl. 24 , figs. $6-8,10-11$.

Neogloboquadrina asanoi $($ Maiya, Saito, and Sato $)=$ Globoquadrina asano Maiyo et al., 1976, p. 409, pl. 3, figs. 1a-c, 2a-c, 3.

Neogloboquadrina dutertrei $(\mathrm{d}$ 'Orbigny) $=$ Globigerina dutertrei d'Orbigny, 1839a, p. 84, pl. 4, figs. 19-21.

Neogloboquadrina humeros (Takayanagi and Saito) $=$ Globorotalia humer osa Takayanagi and Saito, 1962, p. 78, pl. 28, figs. 1-2.

Neogloboquadrina pachyderma (Ehrenberg) = Aristerospira pachyderma Ehrenberg, 1861, p. 276-277, 303.

Orbulina universa d'Orbigny, 1839a, p. 3, pl. 1, fig. 1 .

Pulleniatina obliquiloculata (Parker and Jones) $=$ Pullenia sphaeroides var. obliquiloculata Parker and Jones, 1865, p. 354, pl. 19, fig. 4.

Bolivina argentea Cushman, 1926b, v. 2, pt. 2, no. 29, p. 42, pl. 6, fig. 5 .

Bolivina interjuncta $($ Cushman $)=$ Bolivina costata d'Orbigny var. interjuncta Cushman, 1926b, p. 41 , pl. 6, fig. 3.

Bolivina pseudobeyrichi Cushman, 1926b, p. 45.

Bolivina seminuda Cushman, 1911, v. 71, pt. 2, p. 34, fig. 55.

Bolivina subspinescens Cushman, 1922a, v. 104, p. 48, pl. 7, fig. 5.

Bolivina spissa Cushman $=$ Bolivina subadvena Cushman var. spiss $a$ Cush man, 1926 b, v. 2, pt. 2, p. 45 , pl. 6 , fig. 8

Bolivina translucens Phleger, 1951, pt. 1, p. 15, pl. 7, figs. 13-14.

Bolivinita quadrilatera $($ Schwager $)=$ Textularia quadrilatera Schwager, 1866 , p. 253 , pl. 7 , fig. 10.

Buccella frigida $($ Cushman $)=$ Pulvinulina frigida Cushman, 1922 b, p. 144.

Table 5 (continued).

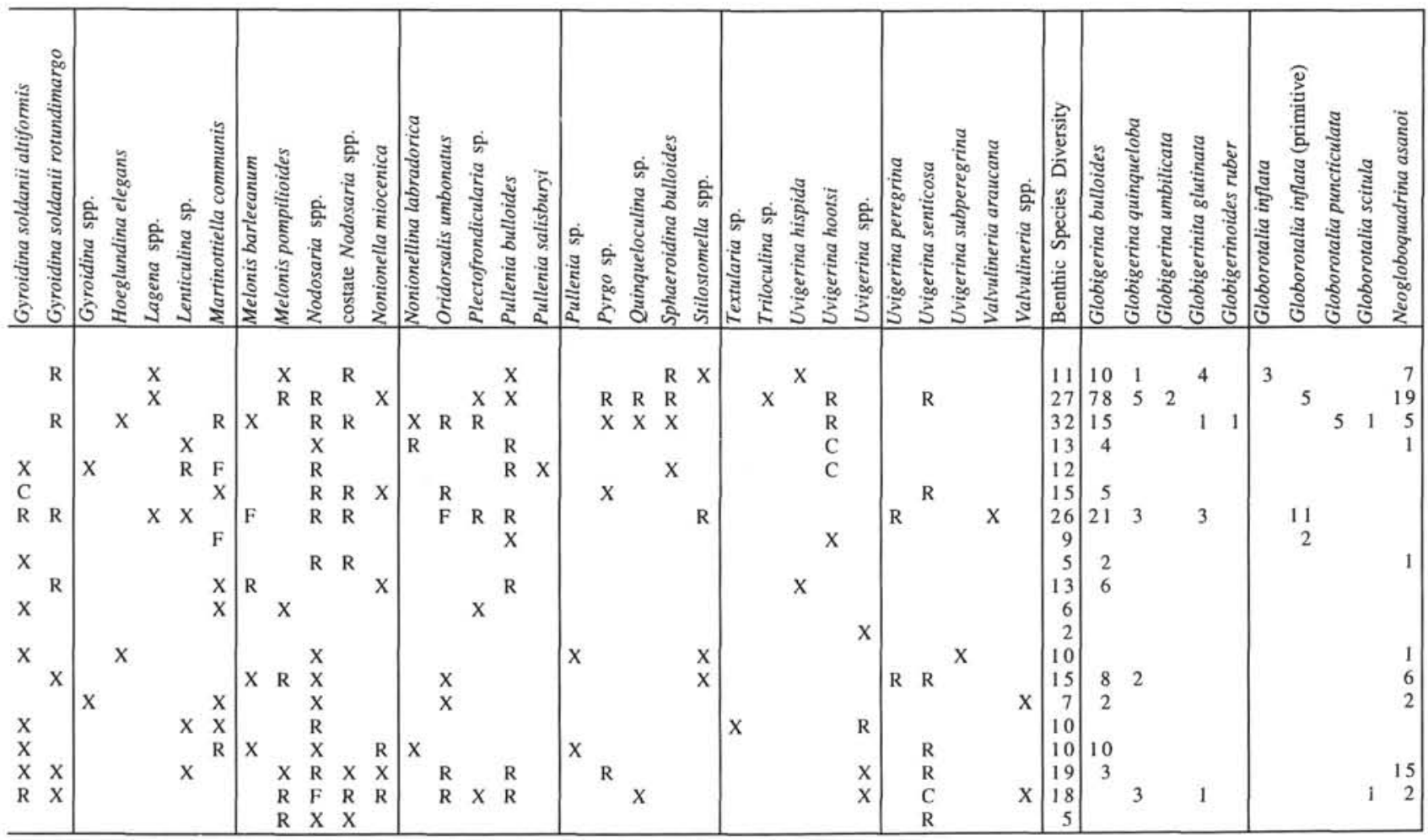


Buccella oregonensis (Cushman, Stewart, and Stewart $=$ Eponides mansfiel di Cushman var. oregonensis Cushman et al., 1947, p. 48, pl. 6, fig. 4.

Buccella tenerrima $($ Bandy $)=$ Rotalia tenerrima Bandy, 1950, p. 278, pl. 42 . fig. 3 .

Bulimina aculeata d'Orbigny, 1826, p. 269.

Bulimina barbata Cushman 1927b, v. 1, no. 10, p. 151, pl. 2, fig. 11.

Bulimina exilis Brady = Bulimina elegans d'Orbigny var. exilis Brady, 1884, v. 9 , no. 22 , p. 399 , pl. 50 , fig. 50 .

Bulimina fossa Cushman and Parker, 1938, v. 14, pt. 3, p. 56, pl. 9, fig. 10.

Bulimina inflata Heron-Allen and Earland, 1913, v. 31, pt. 64, p. 68, pl. 4, fig. 16-19.

Bulimina jacksonensis welcomensis $=$ Bulimina jacksonensis Cushman var. welcomensis Mallory, 1959, p. 193, pl. 16, fig. 7.

Bulimina microcostata Cushman and Parker, 1936, v. 12, p. 39, pl. 7, fig. 2.

Bulimina striata mexicana Cushman and Parker, 1940, v. 16, p. 16, pl. 3, fig. 9.

Bulimina subacuminata Cushman and R. E. Stewart, in Cushman et al., 1930, p. 65 , pl. 5 , figs. $2-3$.

Bulimina subcalva Cushman and K. C. Stewart, in Cushman et al., 1930, p. 65 , pl. 4 , fig. 11.

Buliminella curta Cushman, 1925b, v.1, pt. 2, p. 33, pl. 5, fig. 13.

Buliminella elegantissima $\left(\mathrm{d}^{\prime}\right.$ Orbigny $)=$ Bulimina elegantissima d'Orbigny, 1839 a, p. 51 , p. 7 , figs. $13,14$.

Buliminella subfusiformis Cushman, 1925b, p. 33, pl. 5, fig. 12.

Cassidulina californica Cushman and Hughes, 1925, p. 12, pl. 2, fig. 1.

Cassidulina carinata Silvestri in Todd, 1965, p. 40, pl. 17, fig. 4.

Cassidulina cushmani Stewart and Stewart, 1930, v. 4, p. 71, pl. 9, fig. 5.

Cassidulina limbata Cushman and Hughes, 1925, p. 12, pl. 2, fig. 2.

Cassidulina minuta Cushman, 1933c, p. 92, pl. 10, fig. 3.

Cassidulina norcrossi Cushman, 1933a, p. 7, pl. 2, fig. 7 .

Cassidulina teretis Tappan, 1951, p. 7, pl. 1, fig. 30.

Cassidulina translucens Cushman and Hughes, 1925, p. 15, pl. 2, fig. 5.

Cassidulinoides bradyi $($ Norman $)=$ Cassidulina Brady, Norman in Brady, 1881 , v. 24 , p. 59.

Cassidulinoides cornuta $($ Cushman $)=$ Virgulina cornuta Cushman, 1913, p . 637, pl. 80, fig. 1.

Chilostomella oolina Reuss, 1850, v, 1, p. 380, pl. 48, fig. 12.

Chilostomella ovoidea Reuss, 1850, v. 1, p. 380, pl. 48, fig. 12.

Cibicides perlucida Nuttall, 1932, v. 6, p. 33, pl. 8, figs. 10-12.

Table 5 (continued).

\begin{tabular}{|c|c|c|c|c|c|c|}
\hline $\begin{array}{l}\text { Core, section, } \\
\text { interval }(\mathrm{cm})\end{array}$ & $\begin{array}{l}\text { Depth } \\
\text { (mbsf) }\end{array}$ & 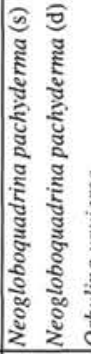 & בั & 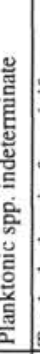 & 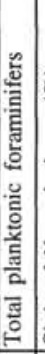 & 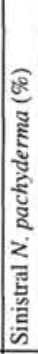 \\
\hline $\begin{array}{l}146.892 \mathrm{~A}- \\
1 \mathrm{X}-\mathrm{CC}\end{array}$ & & & & & & \\
\hline & $\begin{array}{r}4.3 \\
13.2\end{array}$ & 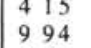 & & 1 & $\begin{array}{l}199 \\
\#\end{array}$ & 21 \\
\hline $3 \mathrm{X}-\mathrm{CC}$ & 22.9 & 042 & & 34 & 45 & 0 \\
\hline $4 \mathrm{X}-\mathrm{CC}$ & 30.4 & & & & 0 & \\
\hline $6 \mathrm{X}-\mathrm{CC}$ & 45,7 & & & 1 & 1 & \\
\hline $7 X-2, \quad 10-15$ & 50.1 & 3 & & & 3 & \\
\hline $7 \mathrm{X}-\mathrm{CC}$ & 57.8 & 732 & & 2 & 41 & 18 \\
\hline $8 \mathrm{X}-\mathrm{CC}$ & 64.7 & 1 & & & 1 & \\
\hline $9 \mathrm{X}-\mathrm{CC}$ & 68.6 & $\begin{array}{ll}1 & 1\end{array}$ & & & 2 & \\
\hline $11 \mathrm{X}-\mathrm{CC}$ & 81.3 & & & 1 & 2 & \\
\hline $12 \mathrm{X}-\mathrm{CC}$ & 88.5 & & & & 0 & \\
\hline $13 \mathrm{X}-\mathrm{CC}$ & 106.0 & & & & 0 & \\
\hline $14 \mathrm{X}-\mathrm{CC}$ & 107.0 & $\begin{array}{ll}1 & 4\end{array}$ & & 1 & 6 & \\
\hline $15 \mathrm{X}-\mathrm{CC}$ & 117.3 & 1321 & & 2 & $36]$ & 38 \\
\hline $16 \mathrm{X}-\mathrm{CC}$ & 126.2 & 2 & & & 2 & \\
\hline $17 \mathrm{X}-\mathrm{CC}$ & 136.7 & & & & 0 & \\
\hline $18 \mathrm{X}-\mathrm{CC}$ & 146.8 & $\begin{array}{ll}3 & 2\end{array}$ & & & 5 & \\
\hline $20 \mathrm{X}-1,87-92$ & 164.4 & 1712 & & 4 & 335 & 59 \\
\hline $20 \mathrm{X}-\mathrm{CC}$ & 167.4 & 3148 & & 5 & 843 & 39 \\
\hline $21 \mathrm{X}-\mathrm{CC}$ & 173.2 & 22 & & 1 & 5 & \\
\hline
\end{tabular}

Cibicidoides mckannai (Galloway and Wissler) $=$ Cibicides mckannai Galloway and Wissler, 1927, p. 65, pl. 10, figs. 5-6.

Cibicidoides wuellerstorfi $($ Schwager $)=$ Anomalina wuellerstorfi Schwager, 1866 , p. 258 , pl. 7, figs $105,107$.

Dentalina spp. - Specimens of this group are often broken.

Eggerella bradyi $($ Cushman $)=$ Verneuilina bradyi Cushman, 1911, p. 54, fig. 87.

Elphidiella hannai $($ Cushman and Grant $)=$ Elphidium hannai Cushman and Grant, 1927, p. 77, pl. 8, fig. 1.

Elphidiella oregonense $($ Cushman and Grant $)=$ Elphidium oregonense Cushman and Grant, 1927, p. 79, pl. 8, fig. 3.

Elphidium excavatum clavatum $=$ Elphidium excavatum $($ Terquem $)$ forma clavata Cushman, 1930 = Elphidium clavatum Cushman, 1930, p. 20, pl. 7, fig. 10.

Epistominella exigua $($ Brady $)=$ Pulvinulina exigua Brady, 1884, p. 696, pl. 103, figs. 13-14.

Epistominella pacifica $($ Cushman $)=$ Pulvinulinella pacifica Cushman, 1927b, p. 165 , pl. 5 , figs. $14-15$.

Eponides healdi Stewart and Stewart, 1930, v. 4, no. 1, p. 70, pl. 8, fig. 8 .

Eponides minima Cushman, 1933b, p. 17, pl. 2, fig. 5.

Fursenkoina bradyi $=$ Virgulina bradyi Cushman, 1922a, v. 104, pt. 3, p. 115, pl. 24 , fig. 1.

Glandulina laevigata d'Orbigny, 1826, p. 252, pl. 10, figs. 1-3.

Globobulimina affinis (d'Orbigny) = Bulimina affinis d'Orbigny 1839a, p. 105 , pl. 2, figs. 25-26.

Globobulimina auriculata $($ Bailey $)=$ Bulimina auriculata Bailey, 1851, p. 12, figs. 25-27.

Globobulimina pacifica Cushman, 1927a, p. 67, pl. 14, fig. 12.

Globocassidulina subglobosa Brady, 1881, p. 60.

Gyroidina orbicularis planata $=$ Gyroidina orbicularis d'Orbigny var. planata Cushman, 1935, p. 45 , pl. 18, fig. 3.

Gyroidina soldanii altiformis = Gyroidina soldanii d'Orbigny var. altiformis Stewart and Stewart, 1930, p. 67, pl. 9, fig. 2.

Gyroidina soldanii rotundimargo = Gyroidina soldanii d'Orbigny var. rotun dimargo Stewart and Stewart, 1930, p. 68, pl. 9, fig. 3.

Hoeglundina elegans $(\mathrm{d}$ 'Orbigny) $=$ Rotalia $($ Turbinulina $)$ elegans d'Orbigny, 1826, p. 276.

"Lagena" spp. - Included in this species groups are all unilocular lagenids

Laticarinina pauperata $($ Parker and Jones) $=$ Pulvinulina repand $a$ Fichtel and Moll var. menardii d'Orbigny subvar. pauperata Parker and Jones, 1865, v. 155 , p. 395 , pl. 16 , figs. $50-51$.

Lenticulina texana (Cushman and Applin $)=$ Cristellaria articulata Reuss var. texana Cushman and Applin, 1926, v. 10, no. 2, pl. 8, fig. 1.

Martinottiella communis (d'Orbigny) = Clavulina communis d'Orbigny, 1826 , p. 268.

Melonis barleeanum $($ Williamson $)=$ Nonionina barleeana Williamson, 1858 , p. 32 , pl. 3, figs. $68-69$.

Melonis pompilioides $($ Fichtel and Moll $)=$ Nautilus pompilioides Fichtel and Moll, 1798, p. 32, pl. 2, figs. a-c.

Nodosaria spp. - costate forms

Nodosaria spp. - noncostate forms

Nonionella globosa Ishiwada, 1950, v. 1, n. 4, pl. 10, fig. 3.

Nonionella miocenica Cushman, 1926a, p. 64.

Nonionella turgida digitata $=$ Nonionella turgida $($ Williamson) var. digitata Nörvang, 1945, p. 29, fig. 4.

Nonionellina labradorica $($ Dawson $)=$ Nonionina labradorica Dawson, 1860 , p. 192 , tf. 4.

Oridorsalis umbonatus (Reuss) $=$ Rotalina umbonata Reuss, 1851, v. 3, p. 75, pl. 5 , fig. 35 .

Plectofrondicularia californica Cushman and Stewart, 1926, p. 39, pl. 6, figs. 9-11.

Pullenia bulloides d'Orbigny, 1846, p. 107, pl. 5, figs. 9-10.

Pullenia salisburyi Stewart and Stewart, 1930, p. 72, pl. 8, fig. 2.

Sphaeroidina bulloides d'Orbigny, 1826, ser. 1, 7:267.

Tosaia hanzawai Takayanagi, 1953, p. 30, pl. 4, fig. 7 .

Trichohyalus ornatissima $($ Cushman $)=$ Discorbis ornatissima Cushman, 1925a, p. 42, pl. 6, figs. 11-12.

Trifarina angulosa $($ Williamson $)=$ Uvigerina angulosa Williamson, $1858, \mathrm{p}$. 67 , pl. 5 , fig. 140.

Trifarina hannai $($ Beck $)=$ Angulogerina hannai Beck, 1943, v. 17, n. 6, p. 607,608 , pl. 108, figs. 26, 28.

Tritaxilina colei Cushman and Siegfus, 1935, p. 92, pl. 14, figs. 5-6.

Uvigerina dirupta Todd $=$ Uvigerina peregrina Cushman var. dirupta Todd, 1948 , v. 6 , no. 5 , p. 267. 
Uvigerina garzaensis Cushman and Siegfus, 1939, v. 15, pl. 28, pl. 6, fig. 15.

Uvigerina hispida Schwager, 1866, v. 2, pt. 2, p. 249, pl. 7, fig. 95.

Uvigerina hootsi Rankin in Cushman and Kleinpell, 1934, v. 10, pt. 1, p. 22 , pl. 3, figs. 8-9.

Uvigerina juncea Cushman and Todd, 1941, p. 78, pl. 20, figs. 4-11.

Uvigerina peregrina Cushman, 1923, p. 166.
Uvigerina senticosa Cushman, 1927b, v. 1, p. 159

Uvigerina subperegrina Cushman and Kleinpell, 1934, v. 10, p. 12, pl. 2, figs. 9-11.

Valvulineria araucana (d'Orbigny) = Rosalina araucana d'Orbigny, $1839 \mathrm{c}$, p. 44 , pl. 6 , figs. $16-18$.

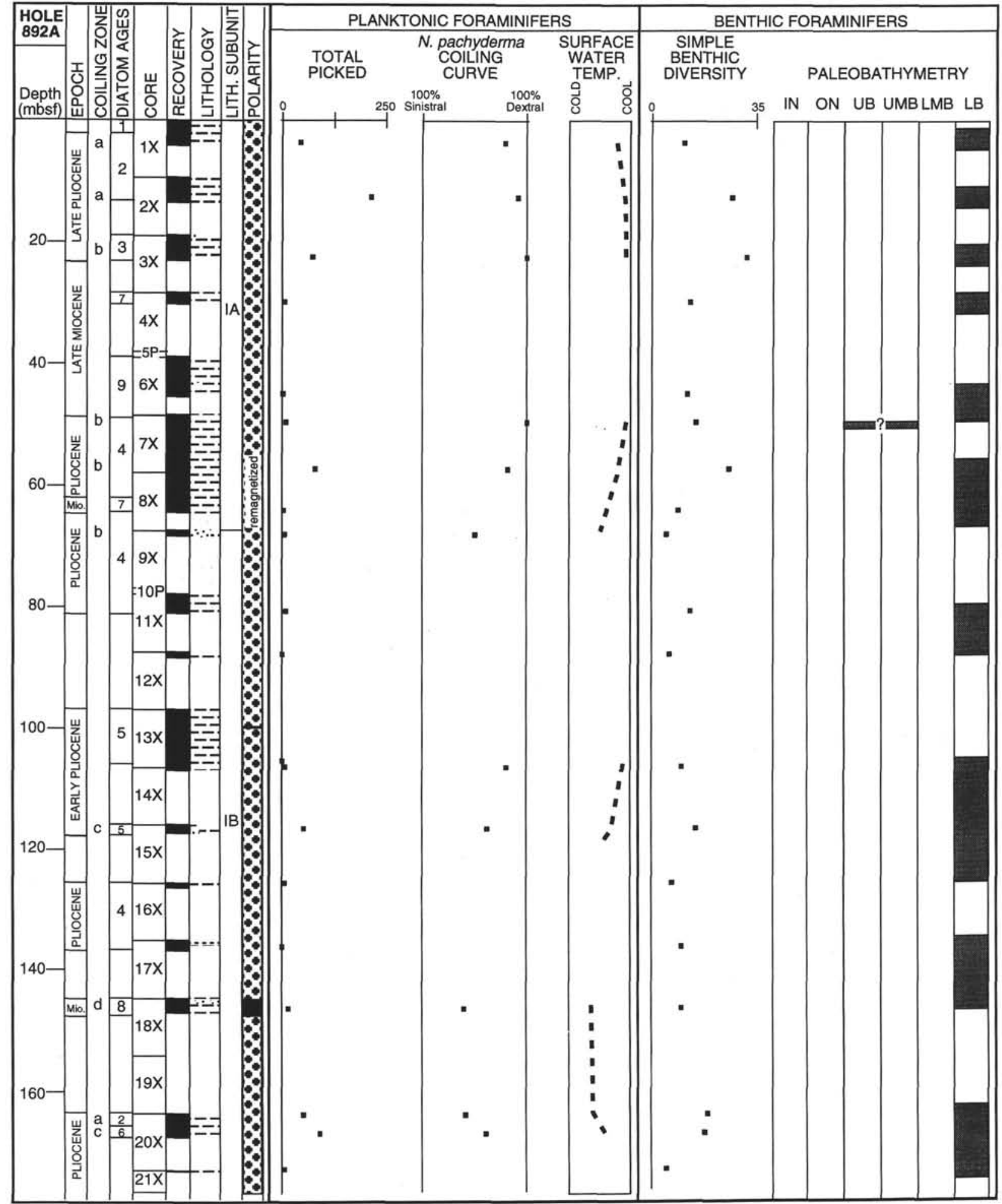

Figure 7. Summary of age zonation, core recovery, lithology, magnetic polarity, foraminiferal distributions, inferred sea-surface temperatures, and paleobathymetry at Hole 892A. Coiling zones, determined by diatom ages (see text), are as follows: $a=C D 12-14 ; b=C D 15 ; c=C D 15-16$; and $d=$ unzoned. Diatom ages (in Ma) are from Fourtanier (this volume) as follows: $1=1.6-0.32 ; 2=2.6-1.6 ; 3=2.7-2.6 ; 4=3.7-2.6 ; 5=5.4-3.75 ; 6=5.4-2.6 ; 7=6.2-6.0 ; 8=6.9-$ 6.6 ; and $9=9.2-8.3$. Key to lithologic symbols: coarse stipple $=$ sand and thin dashed pattern $=$ silt; Key to polarity units: black $=$ normal polarity and cross pattern = demagnetized. A minor fault occurs at $52 \mathrm{mbsf}$ and a fault zone extends from $106.5 \mathrm{mbsf}$ to $160 \mathrm{mbsf}$ (Shipboard Scientific Party, 1994e). See Shipboard Scientific Party (1994e) for more detailed lithologic, paleomagnetic, and structural information. 
Table 6. Checklist of foraminifers found at Hole 892B.

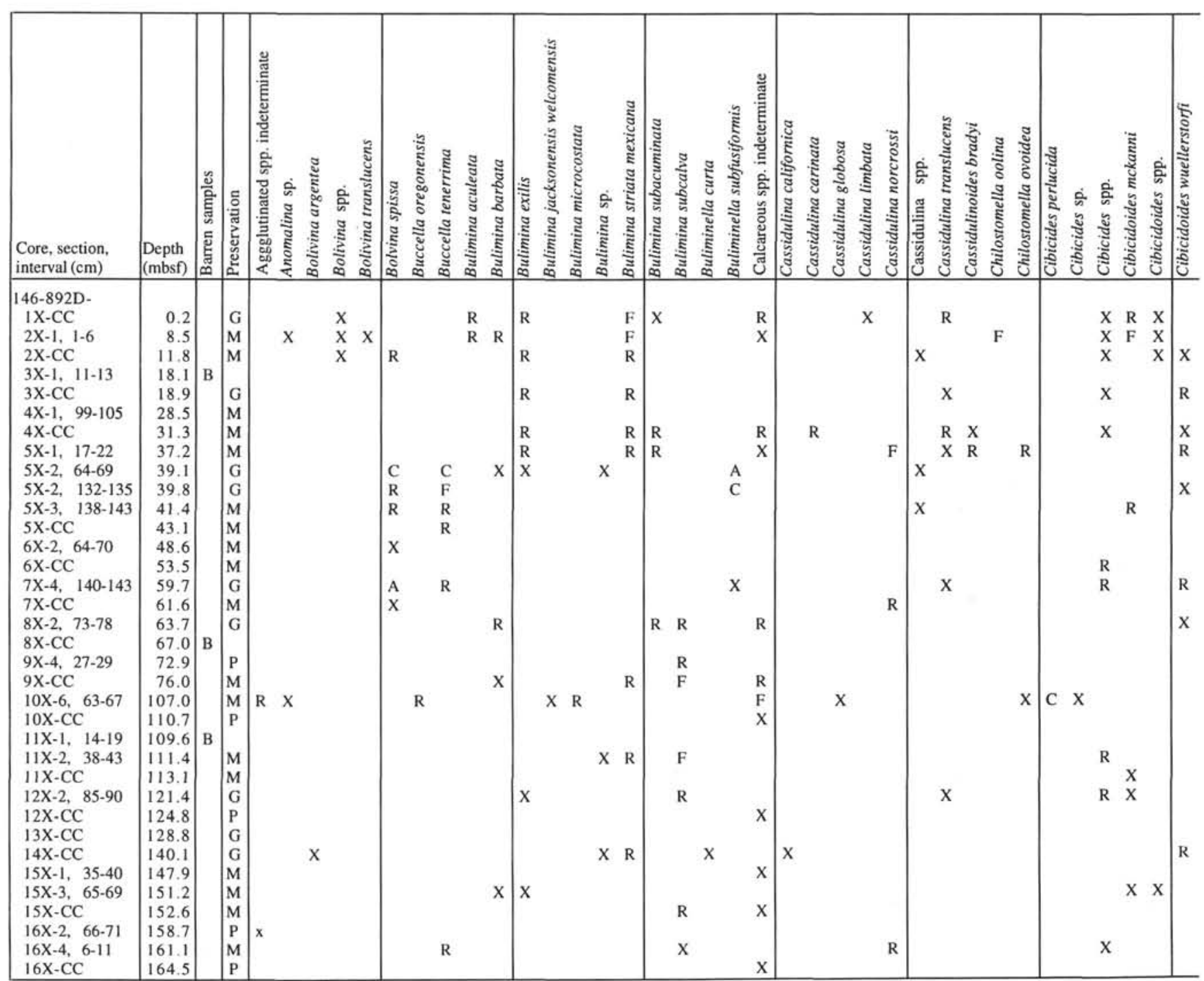

Note: $\mathrm{B}=$ barren samples; see text for explanation of additional abbreviations. 
Table 6 (continued).

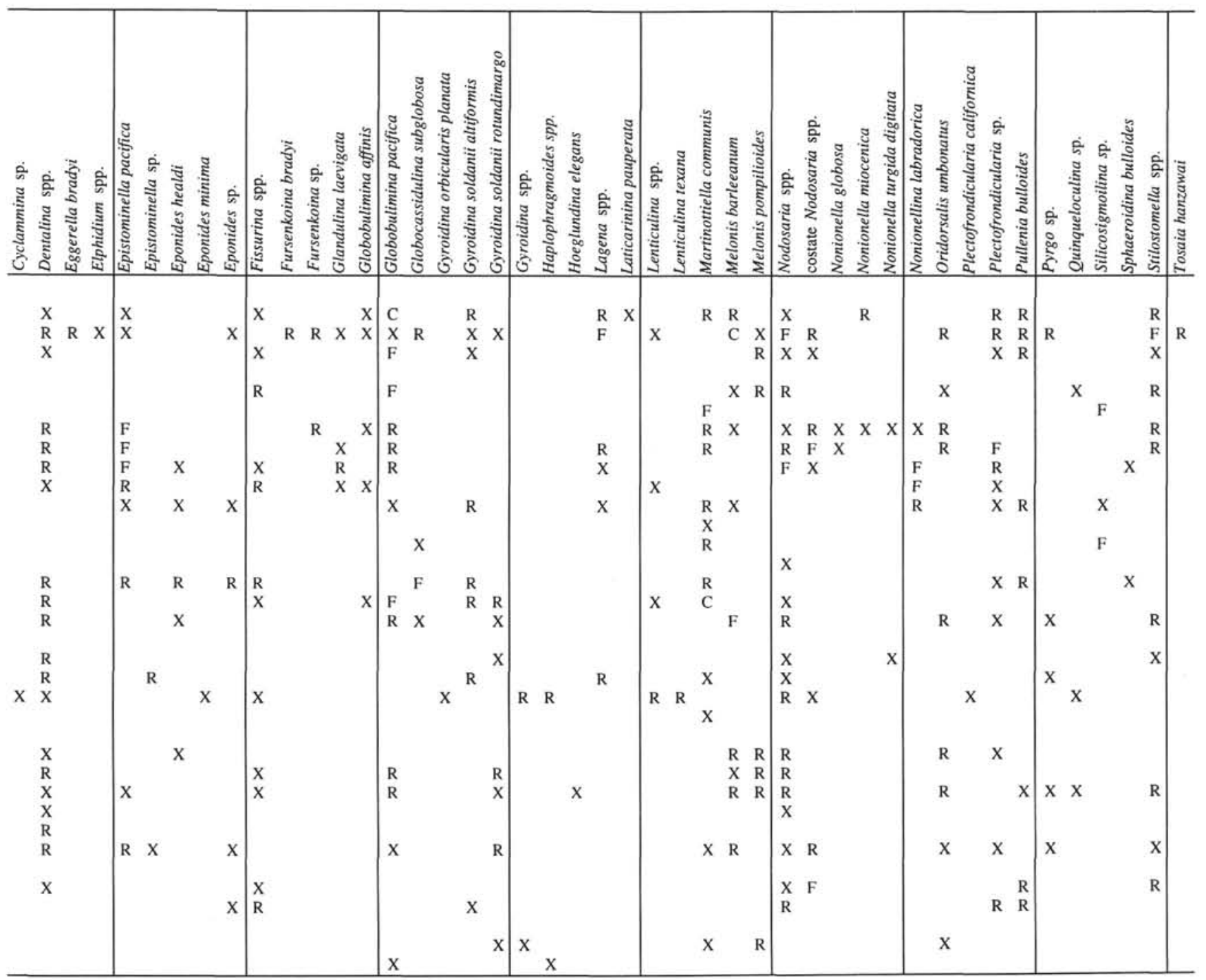


Table 6 (continued).

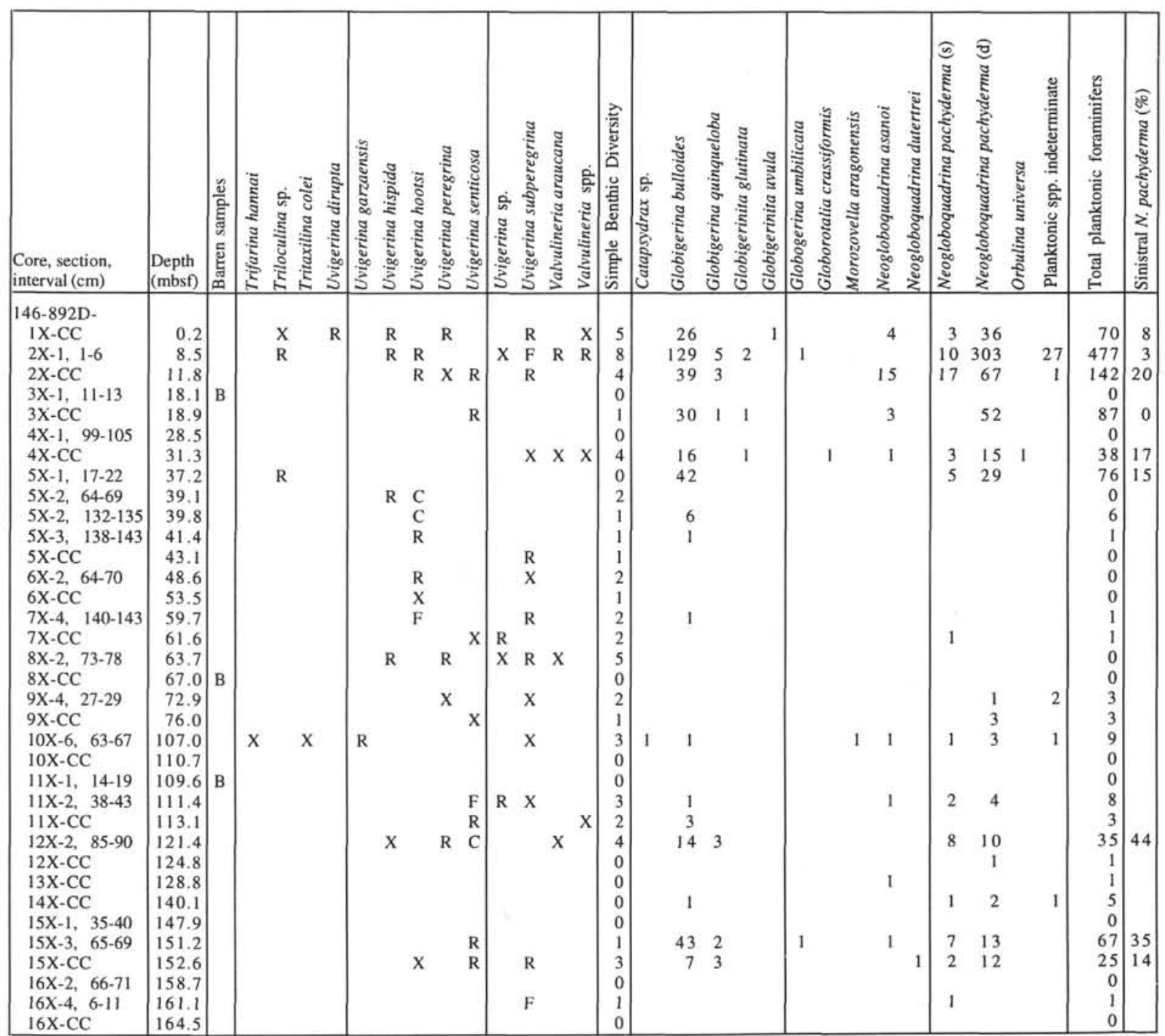




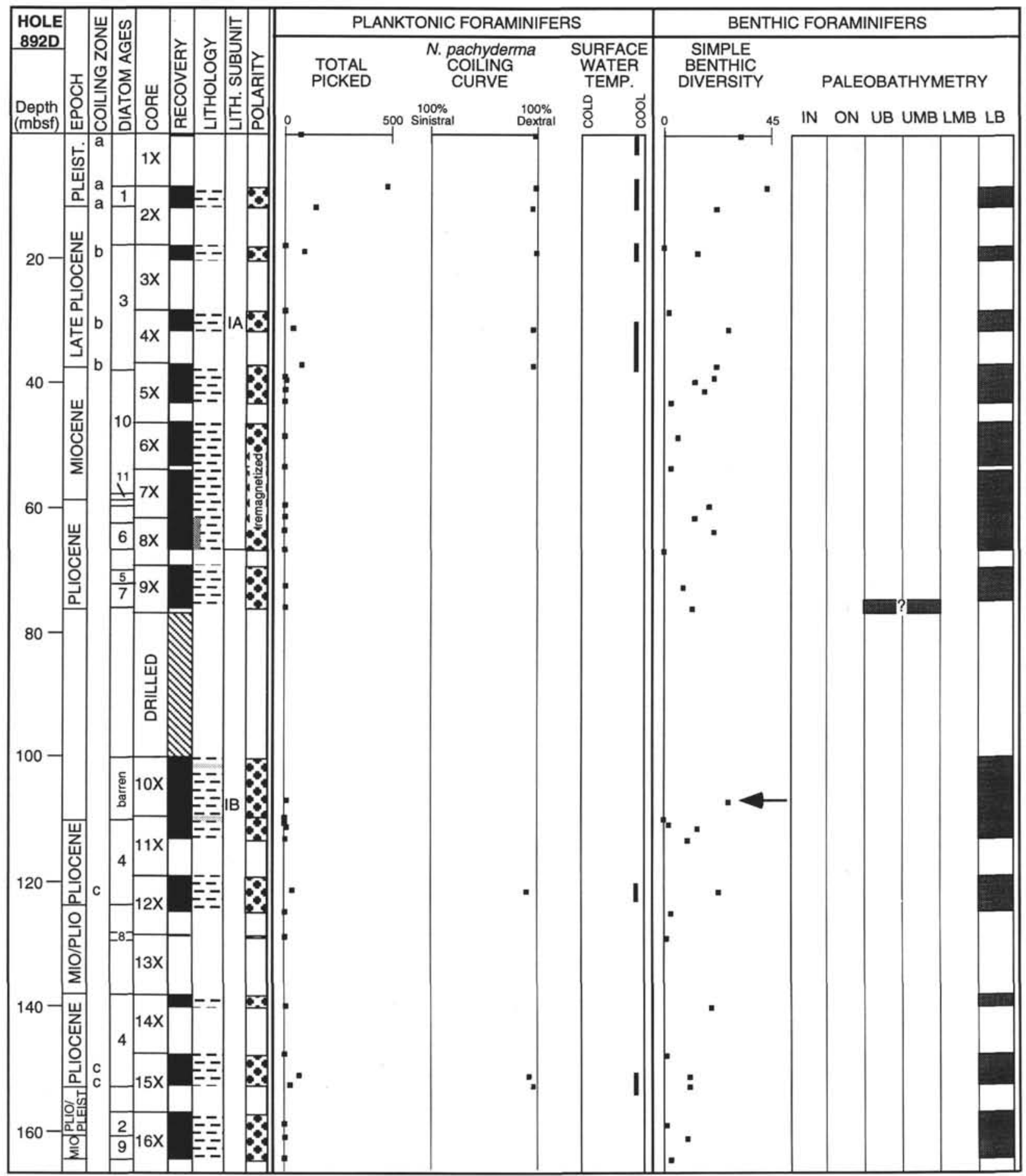

Figure 8. Summary of age zonation, core recovery, lithology, magnetic polarity, foraminiferal distributions, inferred sea-surface temperatures, and paleobathymetry at Hole 892D. Coiling zones, determined by diatom ages (see text), are as follows: $\mathrm{a}=\mathrm{CD} 8-11 ; \mathrm{b}=\mathrm{CD} 11-13$; and $\mathrm{c}=\mathrm{CD} 13$. Diatom ages (in Ma) are from Fourtanier (this volume) as follows: $1=1.6-0.32 ; 2=2.0-0.5 ; 3=2.4 / 2.6-1.6 ; 4=2.7 / 2.6-1.8 ; 5=3.7-2.0 ; 6=3.7-2.6 ; 7=5.4-3.75 ; 8=6.6-5.4 ; 9$ $=7.45-6.5 ; 10=9.2-8.3 ; 11=12.7-11.4$. Key to lithologic symbols: fine stipple $=$ mud and dashed pattern $=$ silt; Key to polarity units: cross pattern $=$ demagnetized. Arrow shows location of Sample 146-892D-10X-6, 63-67 cm. This sample occurs in the top of a fault zone that extends from $100 \mathrm{mbsf}$ to the bottom of the hole (Shipboard Scientific Party, 1994e). See Shipboard Scientific Party (1994e) for more detailed lithologic and paleomagnetic information. 
A

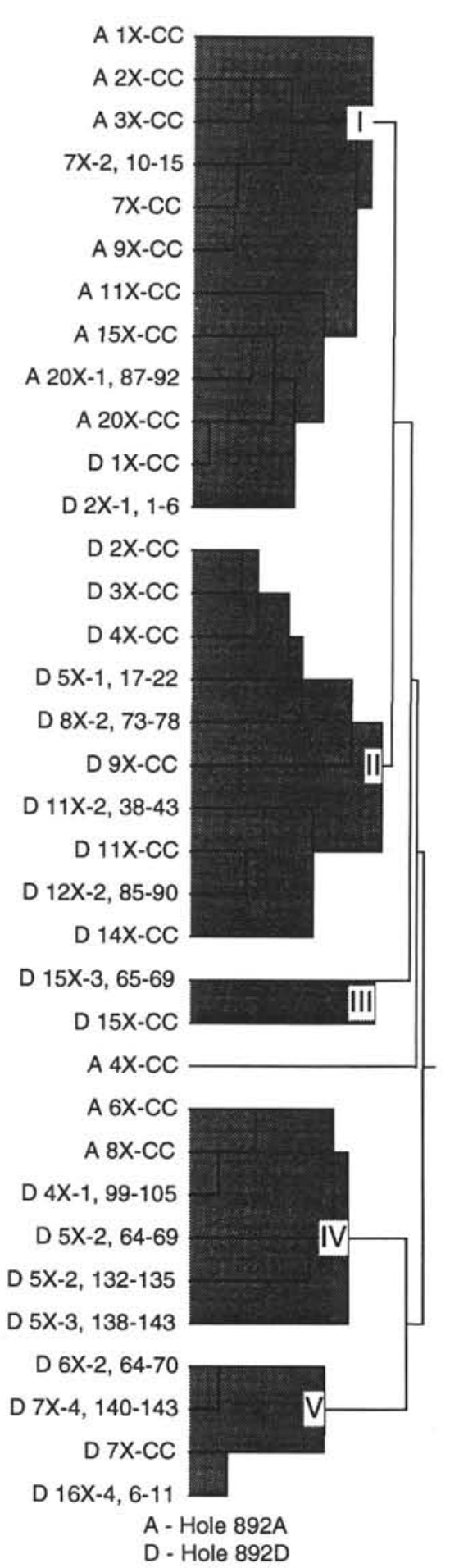

B
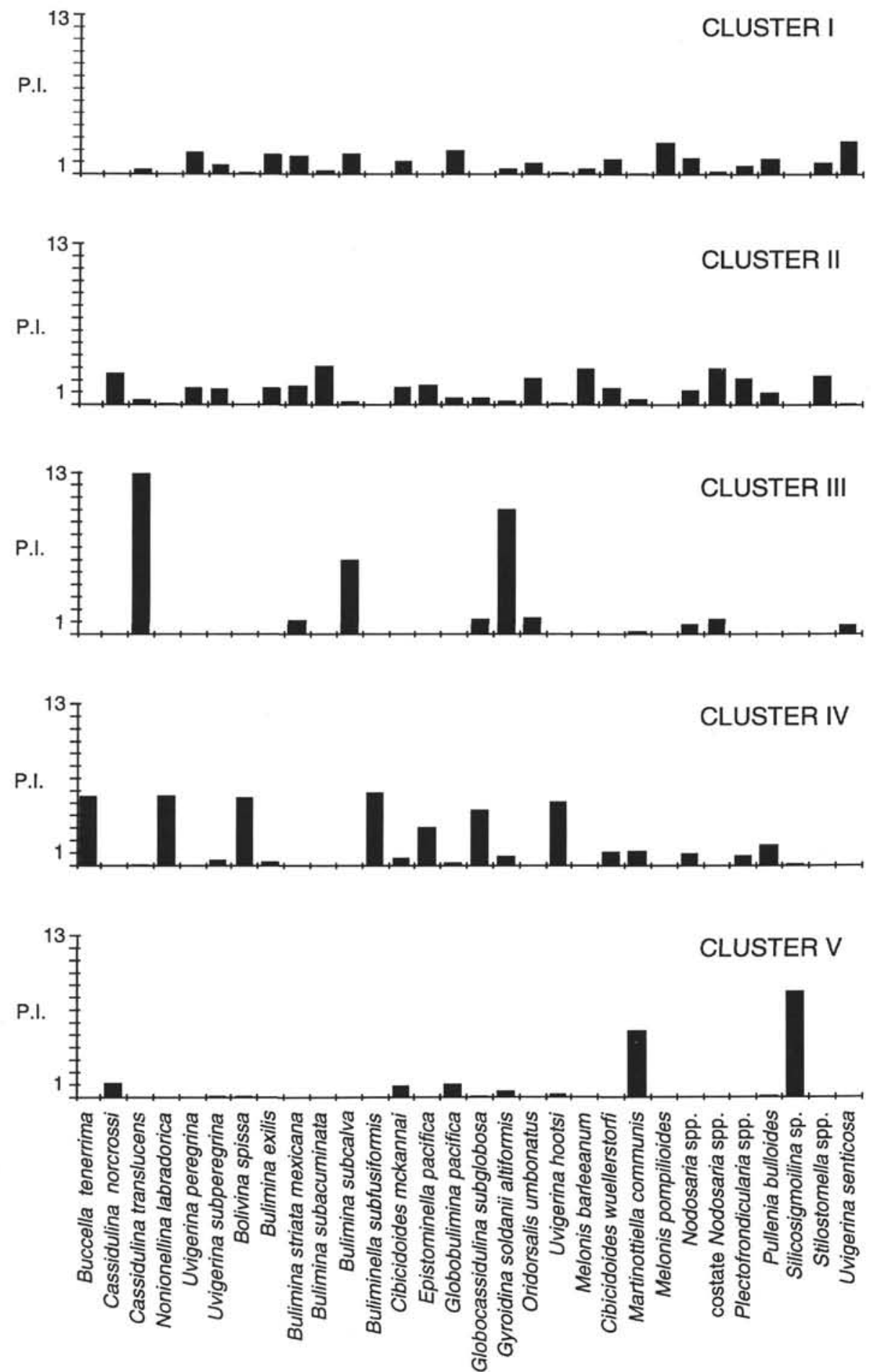

Figure 9. Results of cluster analysis on benthic foraminifers from Site 892. A. Dendrogram. B. Preference indexes for taxa analyzed by cluster analysis (see text). 
A

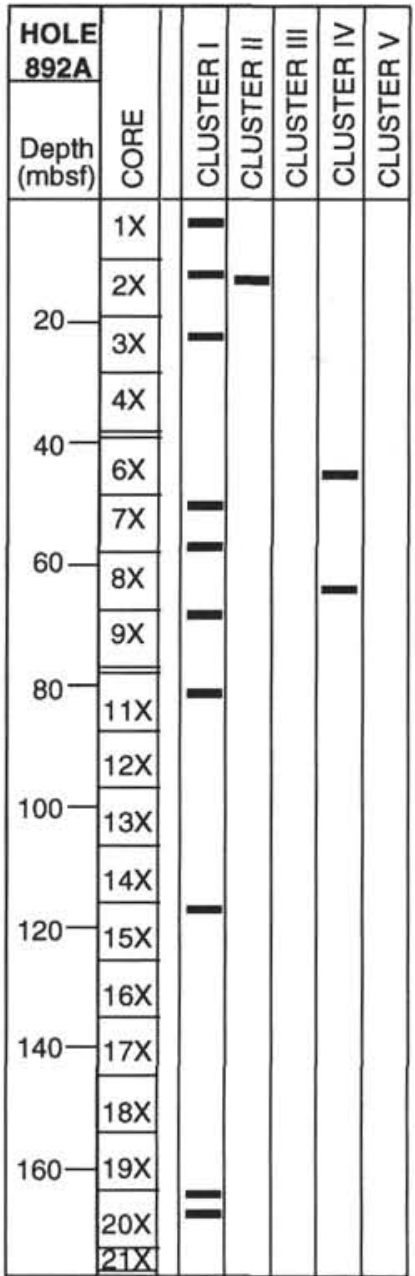

B

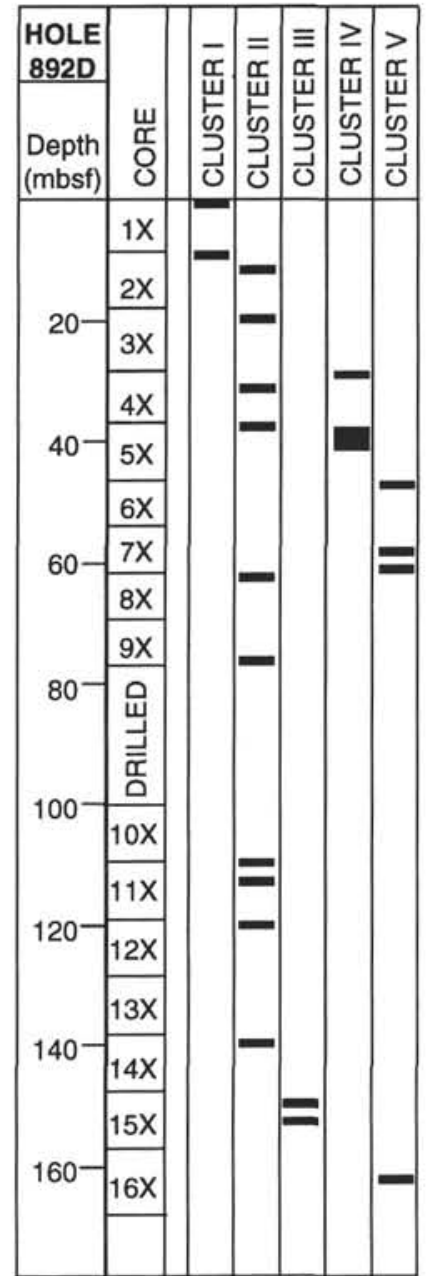

Figure 10. Stratigraphic distribution of samples in each cluster group. A. Hole 892A. B. Hole 892D. 